\title{
The Ediacaran frondose fossil Arborea from the Shibantan limestone of South China
}

\author{
Xiaopeng Wang, ${ }^{1,3}$ Ke Pang, ${ }^{1,4 *}$ (1) Zhe Chen, ${ }^{1,4 *}$ Bin Wan, ${ }^{1,4}$ Shuhai Xiao, ${ }^{2}$ Chuanming Zhou,,${ }^{1,4}$ \\ and Xunlai Yuan ${ }^{1,4,5}$
}

\footnotetext{
${ }^{1}$ State Key Laboratory of Palaeobiology and Stratigraphy, Nanjing Institute of Geology and Palaeontology and Center for Excellence in Life and Palaeoenvironment, Chinese Academy of Sciences, Nanjing 210008, China <xpwang@ nigpas.ac.cn><kepang@nigpas.ac.cn> <zhechen@nigpas.ac.cn> <binwan@nigpas.ac.cn><cmzhou@nigpas.ac.cn><xlyuan@nigpas.ac.cn>

${ }^{2}$ Department of Geosciences, Virginia Tech, Blacksburg, Virginia 24061, USA <xiao@ vt.edu>

${ }^{3}$ University of Science and Technology of China, Hefei 230026, China

${ }^{4}$ University of Chinese Academy of Sciences, Beijing 100049, China

${ }^{5}$ Center for Research and Education on Biological Evolution and Environment, Nanjing University, Nanjing 210023, China
}

\begin{abstract}
Bituminous limestone of the Ediacaran Shibantan Member of the Dengying Formation (551-539 Ma) in the Yangtze Gorges area contains a rare carbonate-hosted Ediacara-type macrofossil assemblage. This assemblage is dominated by the tubular fossil Wutubus Chen et al., 2014 and discoidal fossils, e.g., Hiemalora Fedonkin, 1982 and Aspidella Billings, 1872, but frondose organisms such as Charnia Ford, 1958, Rangea Gürich, 1929, and Arborea Glaessner and Wade, 1966 are also present. Herein, we report four species of Arborea from the Shibantan assemblage, including the type species Arborea arborea (Glaessner in Glaessner and Daily, 1959) Glaessner and Wade, 1966, Arborea denticulata new species, and two unnamed species, Arborea sp. A and Arborea sp. B. Arborea arborea is the most abundant frond in the Shibantan assemblage. Arborea denticulata n. sp. resembles Arborea arborea in general morphology but differs in its fewer primary branches and lower length/width ratio of primary branches. Arborea sp. A and Arborea sp. B are fronds with a Hiemalora-type basal attachment. Sealing by microbial mats and authigenic cementation may have played an important role in the preservation of Arborea in the Shibantan assemblage. The Shibantan material of Arborea extends the stratigraphic, ecological, and taphonomic ranges of this genus.
\end{abstract}

UUID: http://zoobank.org/554f21da-5f09-4891-9deb-cbc00c41e5f1

\section{Introduction}

Ediacara-type macro-organisms are soft-bodied, morphologically complex eukaryotes that flourished in the last 30 million years of the Ediacaran Period ( 571-539 Ma; Pu et al., 2016; Linnemann et al., 2019). These macro-organisms are characterized by unusual body plans with few modern analogs. As such, their phylogenetic affinities have been highly debated, even at the kingdom level (Glaessner, 1979; Seilacher, 1984; Retallack, 1994; Peterson et al., 2003; Xiao and Laflamme, 2009; Erwin et al., 2011). Among all Ediacara-type fossils, frondose forms are some of the most common fossils with wide geographic and long stratigraphic distributions (Laflamme and Narbonne, 2008; Xiao and Laflamme, 2009). They are also phylogenetically diverse (Dececchi et al., 2017, 2018). Rangeomorph fronds (e.g., Charnia Ford, 1958 and Fractofusus Gehling, 2007) dominate the Avalon Assemblage, and arboreomorph fronds (e.g., Arborea Glaessner and Wade, 1966) are also common. In the younger White Sea and Nama assemblages, arboreomorph and

*Corresponding authors erniettomorph fronds overtake rangeomorphs as the dominant fronds, although rangeomorphs continue to persist (Waggoner, 1999; Boag et al., 2016; Droser et al., 2017).

Many Ediacaran fronds are characterized by a stem attached to a leaf-like petalodium at the apical end, and a discoid structure at the basal end, suggesting a benthic lifestyle. Delicate structures of the petalodium could have facilitated osmotrophic feeding (Laflamme et al., 2009, 2018; Hoyal Cuthill and Conway Morris, 2014). But the possibility that they were photoautotrophs has been excluded because of their occurrence in deepmarine environments below the photic zone (Wood et al., 2003). Laflamme and Narbonne (2008) considered Ediacaran fronds as an artificial group, comprising taxa from different phylogenetic lineages, and a recent cladistic analysis by Dececchi et al. (2017) found support for the monophyly of three major frond groups (i.e., rangeomorphs, arboreomorphs, and erniettomorphs; see Laflamme and Narbonne, 2008; Erwin et al., 2011). Xiao and Laflamme (2009), Budd and Jensen (2015), and Dunn et al. (2018) each proposed that rangeomorph fronds are probably metazoans or stem-group metazoans. Hoyal Cuthill and Han (2018) suggested that some Ediacaran fronds might be metazoans on the basis of their purported 
morphological similarities to the Cambrian animal fossil Stromatoveris Shu, Conway Morris, and Han in Shu et al., 2006. Recent studies also suggest that arboreomorphs might be animals as well. Dunn et al. (2019a), for example, concluded that Arborea is a colonial organism belonging to the total-group Eumetazoa, based on evidence for tissue differentiation, fascicled branching arrangement, probable fluid-filled holdfast, and apical-basal and front-back differentiation.

Laflamme et al. (2018) summarized the taxonomic history of Arborea. Arborea arborea (Glaessner in Glaessner and Daily, 1959) Glaessner and Wade, 1966 was first described in the genus Rangea. Glaessner and Wade (1966) recognized its difference from Rangea and erected the new genus Arborea to host this species. Arborea is a frondose fossil with a bifoliate petalodium, a prominent central stalk, parallel primary branches, and sometimes a discoidal holdfast.

Arborea was once synonymized with Charniodiscus Ford, 1958 based on their morphological similarities (Jenkins and Gehling, 1978). However, more recent studies of the original material of Charniodiscus suggest that the holotype of its type species, Charniodiscus concentricus Ford, 1958, could be a multifoliate frond (Dzik, 2002; Brasier and Antcliffe, 2009) with a fractal branching pattern that resembles that of Rangea (Brasier and Antcliffe, 2009). However, all other species placed in the genus Charniodiscus seem to be bifoliate and do not appear to have a fractal branching pattern. Laflamme et al. (2018) considered these characteristics to represent fundamental differences in construction and reassigned Charniodiscus arboreus and Charniodiscus oppositus Jenkins and Gehling, 1978, which are based on Australian specimens, to the genus Arborea. The genus Charniodiscus therefore includes five species, Charniodiscus longus Glaessner and Wade, 1966, Charniodiscus spinosus Laflamme, Narbonne, and Anderson, 2004, Charniodiscus procerus Laflamme, Narbonne, and Anderson, 2004, Charniodiscus yorgensis Borchvardt and Nessov, 1999, and the type species Charniodiscus concentricus. Khatyspytia grandis Fedonkin, 1985 from the terminal Ediacaran Khatyspyt Formation in northern Siberia (Fedonkin, 1985; Grazhdankin, 2014) is said to be "indistinguishable from the Avalon species Charniodiscus procerus" (Grazhdankin et al., 2008, p. 805), but a formal taxonomic treatment has not been published. Further study is needed to determine the taxonomic relationship (or lack thereof) between these Charniodiscus spp. and Arborea. A systematic revision of these Charniodiscus spp. is beyond the scope of the present study, but the morphological differences between Charniodiscus and Arborea spp. are summarized in Table 1.

To contribute to our understanding of Ediacaran frondose fossils, here we provide a systematic description of new arboreomorphs preserved in limestone of the terminal Ediacaran Shibantan Member in the Yangtze Gorges area of South China. The new material includes four species of Arborea: Arborea arborea, Arborea denticulata new species, Arborea sp. A, and Arborea sp. B. These taxa represent the first formal report of Arborea from terminal Ediacaran carbonate facies, and together with possible arboreomorphs from the Khatyspyt Formation in northern Siberia described as Khatyspytia grandis (Fedonkin, 1985; Grazhdankin et al., 2008; Grazhdankin, 2014), they help us to better understand the stratigraphic, ecological, and taphonomic ranges of the Arboreomorpha.

\section{Geological setting}

Cryogenian-Ediacaran successions crop out around the Huangling anticline in the Yangtze Gorges area (Fig. 1.1). Ediacaran successions in this area, consisting of the Doushantuo and Dengying formations, are underlain by the Cryogenian Nantuo Formation and overlain by the Cambrian Yanjiahe Formation (Fig. 1.2). The late Ediacaran Dengying Formation represents the terminal Ediacaran (551-539 Ma) sediments in the Yangtze Gorges area (Condon et al., 2005; Schmitz, 2012). It consists of carbonate rocks deposited in sub- to supratidal inner-ramp environments (Meyer et al., 2014; Duda et al., 2016) on a shallowwater carbonate platform (Cao et al., 1989; Zhou and Xiao, 2007). The Dengying Formation contains three members, in ascending order, the Hamajing, Shibantan, and Baimatuo members (Fig. 1.2).

The fossils described in this paper were collected at the Wuhe section in the Yangtze Gorges area (Fig. 1.1). There, the Hamajing Member is $24 \mathrm{~m}$ thick and is mostly composed of medium- to thick-bedded whitish-gray dolostones with chert concretions and thinly bedded chert bands. Sedimentary evidence for subaerial exposure, e.g., tepee structures and dissolution vugs, is common in the Hamajing Member (Zhou and Xiao, 2007; Meyer et al., 2014). Additional evidence includes calcite pseudomorphs after gypsum crystals (Duda et al., 2016), consistent with the shallow peritidal environment interpretation (e.g., Chen et al., 2013, 2014; Meyer et al., 2014).

The Shibantan Member at Wuhe is $\sim 150 \mathrm{~m}$ thick and consists of blackish-gray, thin- to medium-bedded, bituminous limestone, intercalated with thin chert bands and concretions. Weathered outcrops often display a rusty or ochre color, probably derived from the oxidative weathering of pyrite. The Shibantan Member is generally characterized by microlaminated limestones deposited in subtidal environments, with occasional occurrence of stromatolitic structures indicating deposition in the photic zone, as well as hummocky crossstratification and lenticular rip-up clasts indicating depositional environments above the storm-wave base (Sun, 1986; Meyer et al., 2014; Duda et al., 2016; Xiao et al., 2020). Dark, millimeter-scale, clay-rich, crinkled laminae are also common in the Shibantan Member. These crinkled laminae have been interpreted as microbial mats (Chen et al., 2013), which have been hypothesized to be an important factor facilitating the preservation of soft-bodied Ediacaran fossils (Gehling, 1999; Callow and Brasier, 2009; Laflamme et al., 2011). A number of macrofossil taxa have been reported from the Shibantan Member, including classical Ediacara-type fossils (e.g., Rangea Gürich, 1929, Pteridinium Gürich, 1930, and Hiemalora Fedonkin, 1982; Chen et al., 2014), macroalgal fossils such as Vendotaenia Gnilovskaya, 1971 (Zhao et al., 1988), problematic fossils such as Yangtziramulus Shen et al., 2009 (Xiao et al., 2005) and Curviacus Shen et al., 2017, as well as remarkably diverse trace fossils that provide exciting opportunities to study early animal evolution (Zhao et al., 1988; Weber et al., 2007; Chen et al., 2013, 2018, 2019; Meyer et al., 2014; Xiao et al., 2019).

The Baimatuo Member at Wuhe is $\sim 60 \mathrm{~m}$ thick and is composed of medium- to thick-bedded light gray dolostones. Similar to the Hamajing Member, dissolution structures, tepees, and 
Table 1. Comparison of taxa of Charniodiscus and Arborea. $\mathrm{NP}=$ not preserved; * = type species; $-=$ no data. References: $1=$ Ford $(1958) ; 2=$ Brasier and Antcliffe (2009); $3=$ Laflamme et al. (2004); $4=$ Glaessner and Wade (1966); 5 = Ivantsov (2016); 6 = Glaessner and Daily (1959); 7 = Hofmann et al. (2008); $8=$ Laflamme et al. (2018); $9=$ Jenkins and Gehling (1978).

\begin{tabular}{|c|c|c|c|c|c|c|c|c|}
\hline Species & $\begin{array}{l}\text { Charniodiscus } \\
\text { concentricus* }\end{array}$ & Charniodiscus procerus & Charniodiscus spinosus & Charniodiscus longus & Charniodiscus yorgensis & Arborea arborea* & Arborea oppositus & $\begin{array}{l}\text { Arborea denticulata } \\
\text { n. sp. }\end{array}$ \\
\hline $\begin{array}{l}\text { Petalodium length/ } \\
\text { width ratio }\end{array}$ & 2.6 & 2.6 & 2.0 & 2.5 & 5.9 & 3.7 & $2.5-4.0$ & 3.3 \\
\hline $\begin{array}{l}\text { Petalodium length } \\
\text { (cm) }\end{array}$ & 16.2 & $4.7-15.4($ mean $9.3, \mathrm{~N}=14)$ & $\begin{array}{c}3.9-16.4(\text { mean } 10, \\
N=28)\end{array}$ & 15 & 0.75 & to 60 & to 73 & 6 \\
\hline $\begin{array}{l}\text { Petalodium width } \\
\text { (cm) }\end{array}$ & 6.3 & $1.5-5.7($ mean $3.6, \mathrm{~N}=14)$ & $\begin{array}{c}1.8-9.8(\text { mean } 5.2, \\
N=28)\end{array}$ & 6 & 1.28 & to 10 & to 30 & 1.8 \\
\hline Petalodium shape & multifoliate, ovate & $\begin{array}{l}\text { bifoliate, lanceolate, typically } \\
\text { bent to one side of stem }\end{array}$ & bifoliate, ovate & $\begin{array}{l}\text { bifoliate, fusiform to } \\
\text { elongate }\end{array}$ & $\begin{array}{l}\text { bifoliate, elongated } \\
\text { lanceolate }\end{array}$ & bifoliate, ovate & bifoliate, elliptic & bifoliate, elliptic \\
\hline $\begin{array}{l}\text { Primary branches } \\
(\#)\end{array}$ & $>17$ & $<15$ & $<15$ & $>17$ & $>27$ & $>14$ & $\sim 30$ & 13 \\
\hline $\begin{array}{l}\text { Primary branches } \\
\text { diverging angle }\end{array}$ & $45-70^{\circ}$ & $45-90^{\circ}$ & $45-90^{\circ}$ & $\begin{array}{l}25-50^{\circ}, \text { steeper near } \\
\text { apex }\end{array}$ & acute & $60-80^{\circ}$ & $65-85^{\circ}$ & $75-90^{\circ}$ \\
\hline $\begin{array}{l}\text { Primary branches } \\
\text { length/width } \\
\text { ratio }\end{array}$ & 4.7 & 2.5 & 3.4 & $3-6$, commonly 5 & 6.3 & 4.5 & $\begin{array}{l}\text { 3-3.5 (on more } \\
\text { central parts of } \\
\text { frond) }\end{array}$ & $1.4-2.1$ \\
\hline $\begin{array}{l}\text { Primary branches } \\
\text { arrangement }\end{array}$ & alternate & alternate & alternate or opposite & alternate & alternate & alternate & $\begin{array}{c}\text { bilateral } \\
\text { (approximate) }\end{array}$ & alternate \\
\hline Holdfast & $\begin{array}{l}\text { discoidal, some } \\
\text { bearing concentric } \\
\text { rings }\end{array}$ & $\begin{array}{l}\text { discoidal, unornamented, } \\
\text { lacking concentric rings, with } \\
\text { central boss }\end{array}$ & discoidal & NP & $\begin{array}{l}\text { discoidal with central } \\
\text { boss }\end{array}$ & discoidal & $\mathrm{NP}$ & $\begin{array}{l}\text { discoidal with } \\
\text { concentric rings and } \\
\text { central boss }\end{array}$ \\
\hline $\begin{array}{l}\text { Holdfast } \\
\text { dimensions } \\
(\mathrm{cm})\end{array}$ & diameter 6.4 & $\begin{array}{c}\text { diameter } \begin{array}{c}1.6-5.4(\text { mean } 3.3, \\
N=14)\end{array}\end{array}$ & $\begin{array}{l}\text { diameter } 0.3-16.4 \\
(\text { mean } 4.4, \mathrm{~N}=28)\end{array}$ & NP & $\begin{array}{c}\text { long axis of distorted } \\
\text { basal disk 1.42, short axis } \\
1.1\end{array}$ & diameter 6.1 & NP & diameter 1.2 \\
\hline Stem $(\mathrm{cm})$ & length 4 & $\begin{array}{l}\text { prominent, representing greatest } \\
\text { portion of length, length } \\
3.1-13.6 \text { (mean } 6.9, \mathrm{~N}=14)\end{array}$ & $\begin{array}{c}\text { length } 0.5-5.7 \text { (mean } \\
2.2, \mathrm{~N}=28 \text { ) }\end{array}$ & NP & absent & length 5 & present & $\begin{array}{l}\text { not prominent, } \\
\text { length } 2.9\end{array}$ \\
\hline $\begin{array}{l}\text { Petalodium length/ } \\
\text { holdfast } \\
\text { diameter ratio }\end{array}$ & 2.5 & 3.0 & 2.6 & (holdfast NP) & 6.0 & 4.3 & - & 4.2 \\
\hline $\begin{array}{l}\text { Petalodium length/ } \\
\text { stem length ratio }\end{array}$ & 4.1 & 1.6 & 5.8 & (stem NP) & (stem absent) & 5.2 & - & 2.2 \\
\hline $\begin{array}{l}\text { Central stalk } \\
\text { Secondary } \\
\text { branches }\end{array}$ & $\begin{array}{c}\text { absent } \\
\text { present, exhibiting } \\
\text { fractal braching } \\
\text { pattern }\end{array}$ & $\begin{array}{l}\text { present } \\
\text { present }\end{array}$ & $\begin{array}{c}\text { present } \\
\text { present, } \\
\text { subperpendicular to } \\
\text { primary branches }\end{array}$ & $\begin{array}{c}\text { present } \\
\text { present, } \\
\text { subperpendicular to } \\
\text { primary branches }\end{array}$ & $\begin{array}{l}\text { present } \\
\text { present, subperpendicular } \\
\text { to primary branches }\end{array}$ & $\begin{array}{l}\text { varies in shape } \\
\text { present, perpendicular to } \\
\text { primary branches; length }\end{array}$ & $\begin{array}{l}\text { present } \\
\text { present }\end{array}$ & $\begin{array}{l}\text { not prominent } \\
\text { NP }\end{array}$ \\
\hline Other features & non & none & $\begin{array}{l}\text { apex ornamented with } \\
\text { spine }\end{array}$ & none & $\begin{array}{l}\text { primary branches curvy, } \\
\text { narrow outward }\end{array}$ & $\begin{array}{l}\text { primary branches narrow } \\
\text { slightly distally }\end{array}$ & none & none \\
\hline Occurrence & $\begin{array}{l}\text { Leicestershire, } \\
\text { England }\end{array}$ & Newfoundland, Canada & Newfoundland, Canada & South Australia & White Sea, Russia & $\begin{array}{l}\text { South Australia; } \\
\text { Newfoundland, Canada; } \\
\text { Yangtze Gorges, China }\end{array}$ & South Australia & $\begin{array}{l}\text { Yangtze Gorges, } \\
\text { China }\end{array}$ \\
\hline References & 1,2 & 3 & 3 & 4 & 5 & $3,4,6-8$ & 9 & this study \\
\hline
\end{tabular}




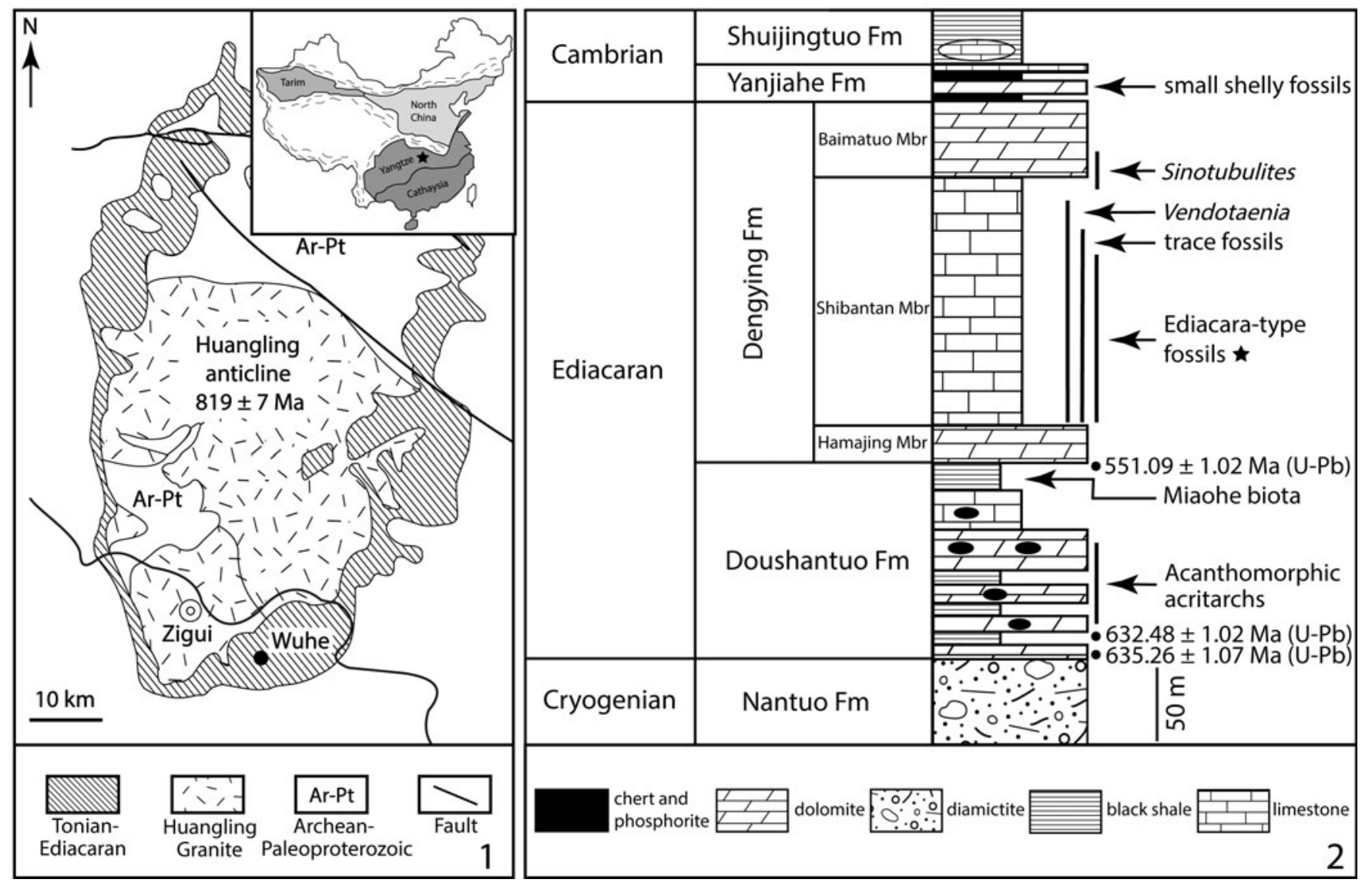

Figure 1. Geological map (1) and stratigraphic column (2) showing the locality of the Wuhe quarry [black dot in (1)] and the stratigraphic range of Ediacara-type fossils [black star in (2)]. Arborea fossils reported in this paper were collected from two horizons at $0.5 \mathrm{~m}$ and $20 \mathrm{~m}$ above the base of the Shibantan Member. Modified from Chen et al. (2014). Geochronometric data from Condon et al. (2005) and Schmitz (2012). Fm = Formation; Mbr $=$ Member; U-Pb $=$ uranium-lead radiometric dating.

intraclasts are common in the Baimatuo Member, indicating deposition in a peritidal environment (Zhou and Xiao, 2007).

\section{Materials and methods}

The Arborea specimens described here were collected from the Shibantan limestone at the Wuhe quarry $\left(30.789^{\circ} \mathrm{N}, 110.051^{\circ} \mathrm{E}\right)$ with known stratigraphic orientation (Fig. 1.1). Two fossiliferous horizons were recorded, at $\sim 0.5 \mathrm{~m}$ and $20 \mathrm{~m}$ above the base of the Shibantan Member. Petrographic thin sections were prepared for one Arborea arborea specimen and observed under a transmitted light microscope. One of the specimens (NIGP 170063, Fig. 2.1) was previously illustrated by Droser et al. (2017, fig. 1, top left), but all other specimens are illustrated here for the first time.

A principal component analysis (PCA) was conducted to assist taxonomic identification and to evaluate morphological similarities among Arborea species. The analysis was based on morphological data collected from 20 specimens with a complete petalodium, including eight Arborea arborea specimens and one Arborea denticulata n. sp. specimen from South China (this paper), three Arborea arborea specimens from South Australia (Laflamme et al., 2018; Dunn et al., 2019a), and five Charniodiscus sp. specimens and three "Charniodiscus" arboreus specimens from Newfoundland (Laflamme et al., 2004; Hofmann et al., 2008). Measurements of Newfoundland specimens were taken on retrodeformed photos (with elliptical holdfasts restored to their original circular shape; Hofmann et al., 2008) because the host sediments are known to have been tectonically deformed. One exception is the specimen ROM 36504, which was discovered on a loose block near Portugal Cove South and contains a circular holdfast indicating locally negligible shearing (Laflamme et al., 2004). No retrodeformation was performed on specimens from South Australia and South China, where discoidal holdfasts are mostly circular in shape, indicating very little tectonic deformation. Seven morphological variables were measured, including the widths of the stem (measured at the base of the petalodium) and stalk, the widths and lengths of the petalodium and the largest primary branch, and the number of primary branches (Table 2). The biometric data were presented in cross-plots and fed into PCA analysis. The PCA analysis was performed using the PAST software (Hammer et al., 2001).

Repository and institutional abbreviation.-All illustrated specimens are deposited in the Nanjing Institute of Geology and Palaeontology (NIGP), Nanjing, China. Additional specimens for PCA and biometric analysis (Table 3) are housed at The Royal Ontario Museum (ROM), Toronto, Canada; the Provincial Museum of Newfoundland and Labrador (NFM F), St. John's, 

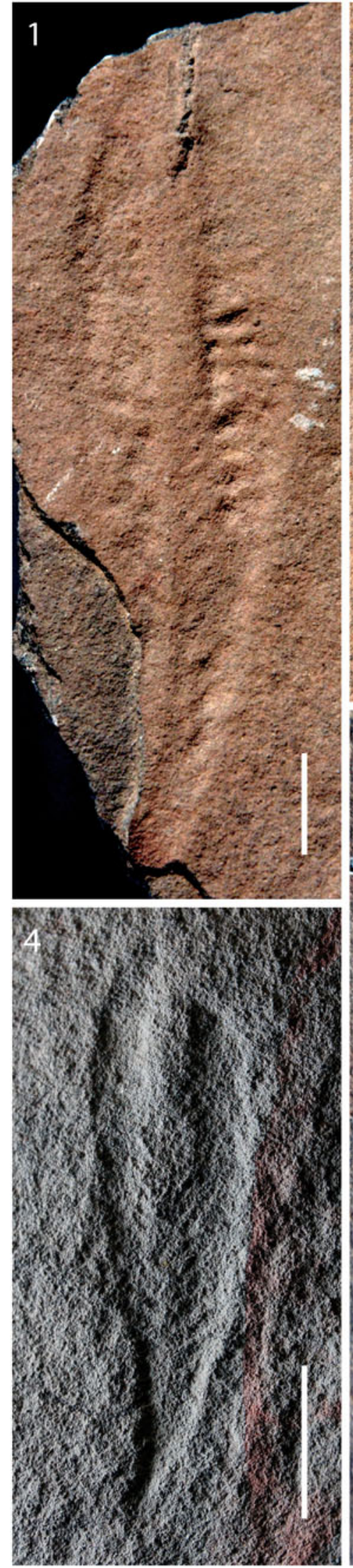
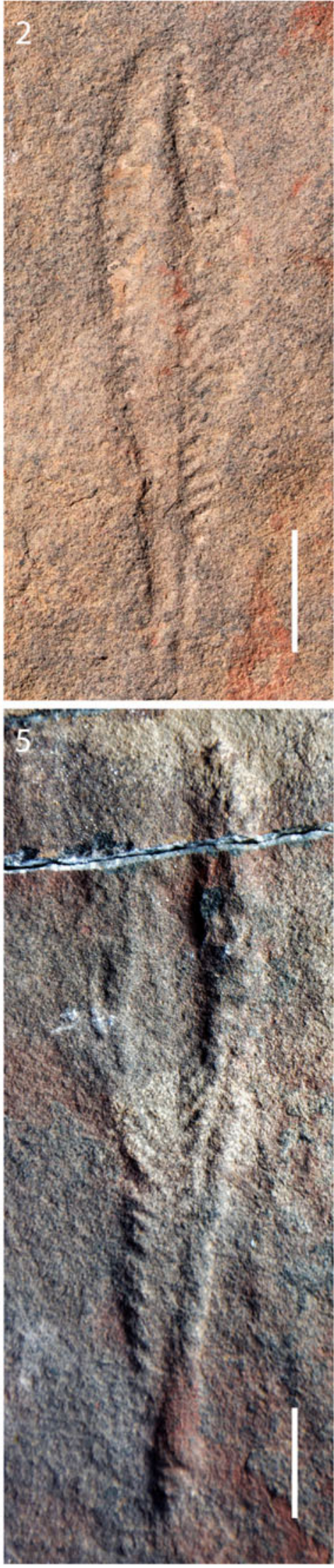

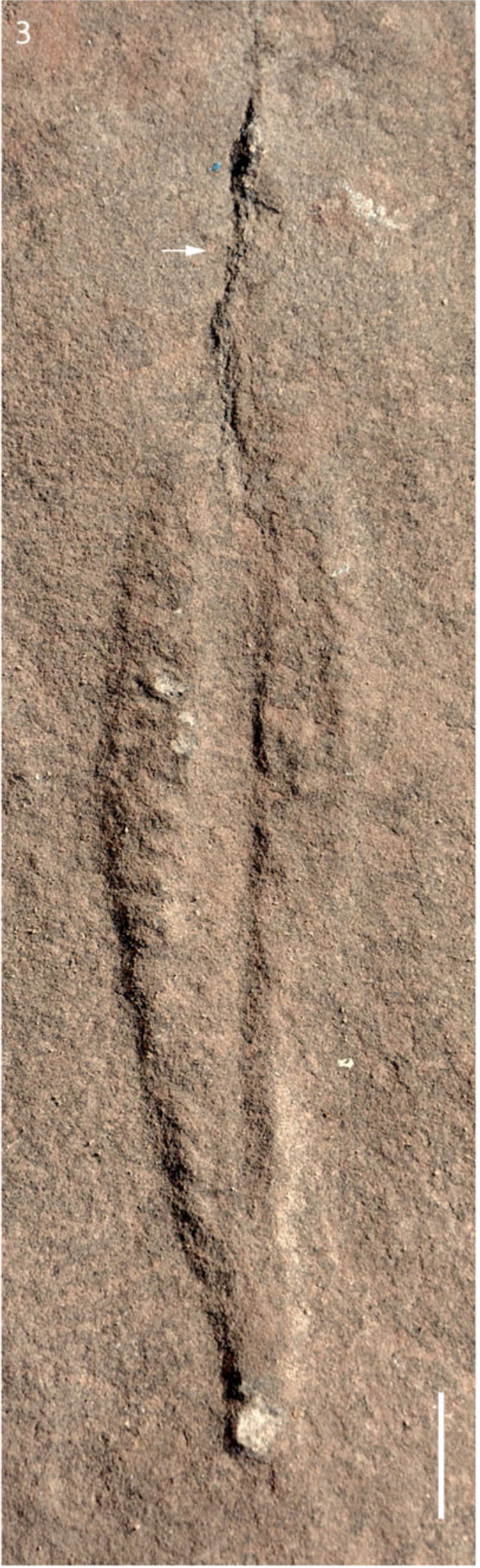


Figure 2. Arborea arborea from the Shibantan limestone: (1) nearly complete specimen with central stalk and primary branches preserved in positive relief, bed sole view, NIGP 170063; (2) specimen with stalk preserved as central furrow, bed top view, field specimen; (3) counterpart of specimen in (1), spine-like structure (arrow) extends beyond apex of the petalodium; (the spine-like structure appears to be a crack rather than a biological feature, and no such structure is present in other specimens; bed top view, NIGP 170063; (4) small but nearly complete specimen, with stalk that does not extend through entire length of the petalodium, bed sole view, NIGP 170065; (5) nearly complete specimen, bed top view, NIGP 170066. Scale bars $=1 \mathrm{~cm}$.

Canada; and the South Australian Museum (SAM P), Adelaide, Australia.

\section{Systematic paleontology}

Genus Arborea Glaessner and Wade, 1966

Type species.-Arborea arborea (Glaessner in Glaessner and Daily, 1959) Glaessner and Wade, 1966.

Arborea arborea (Glaessner in Glaessner and Daily, 1959) Glaessner and Wade, 1966, emended

Figure 2

1959 Rangea arborea Glaessner in Glaessner and Daily, p. 383-387, pls. 43.1-43.3, 44.1-44.3, 45.1, 45.2, 46.1.

1966 Arborea arborea; Glaessner and Wade, p. 619-620, pl. 102, figs. 1, 2.

1978 Charniodiscus arboreus; Jenkins and Gehling, fig. 3.

1979 Charniodiscus arboreus; Glaessner, fig. 12.2c.

1996 Charniodiscus arboreus; Jenkins, p. 36, fig. 4.2a, b, 4.3.

2002 Charniodiscus (Arborea) arboreus; Dzik, fig. 4.

2004 Charniodiscus arboreus; Laflamme et al., p. 832, fig. 4.5.

2004 frond-like fossils; O'Brien and King, p. 206, fig. 3A, 3B, pls. 3C, 4A.

2008 Charniodiscus arboreus; Hofmann et al., p. 20, fig. 16.7-16.8.

2008 Charniodiscus sp.; Hofmann et al., p. 23, fig. 16.1-16.6.

2013 Charniodiscus sp.; Gehling and Droser, fig. 2c.

2014 Charniodiscus; Chen et al., fig. 3c.

2017 Arborea; Droser et al., fig. 1 (top left specimen).

2018 Arborea; Laflamme et al., p. 4-7, figs. 1-8.

2019a Arborea; Dunn et al., figs. 1-5.

Holotype.-SAM P 12891, from the Ediacaran Member of the Rawnsley Quartzite, Flinders Ranges, South Australia.

Emended diagnosis (from Laflamme et al., 2004).—Arborea with ovate petalodium and at least 14 primary branches alternating on either side of stalk. Primary branches approximately uniform in width throughout petalodium, with distal branches slightly narrower than proximal ones.

Occurrence.-Shibantan Member, Dengying Formation, Yangtze Gorges area of South China (Chen et al., 2014); Mistaken Point and Fermeuse formations, Newfoundland, Canada (Laflamme et al., 2004; Hofmann et al., 2008); Rawnsley Quartzite, Flinders Ranges, South Australia (Glaessner and Wade, 1966).
Description.-The Shibantan specimens are characterized by a bifoliate frond with 15-21 primary branches emanating from a prominent stalk at $40-90^{\circ}$. Oblanceolate petalodium tapers toward an apex at the distal end, connecting to a basal disc (holdfast) via a stem at the other end. The best-preserved specimen, consisting of a part and counterpart (NIGP 170063, Fig. 2.1, 2.3), is nearly complete, with fully preserved petalodium but missing the stem and holdfast. The petalodium is $80 \mathrm{~mm}$ in length, $25 \mathrm{~mm}$ in width, preserved as positive hyporelief in limestone. Two rows of primary branches attach alternately to a central stalk. Primary branches are better preserved on one side of the petalodium (Fig. 2.1, right), where 16 primary branches are discernable. Primary branches are 1.6$3.3 \mathrm{~mm}$ in width (measured along the length of the stalk) and $6.7-11.6 \mathrm{~mm}$ in length (measured perpendicular to the length of the stalk). The length/width ratio of primary branches is 3.5-4.2 (3.5 for the largest primary branch). Branching angles of primary branches increase from $40^{\circ}$ at the base of the petalodium to almost $90^{\circ}$ at the apex. Secondary branches were not discernable. The stalk is parallel-sided, $7 \mathrm{~mm}$ wide. Other specimens (three of which are illustrated in Fig. 2.2, 2.4, 2.5) show a similar petalodium shape, with a petalodium length of $40-262 \mathrm{~mm}$ (mean $87 \mathrm{~mm}, \mathrm{~N}=16$ ) and petalodium width of $12-51 \mathrm{~mm}$ (mean $22 \mathrm{~mm}, \mathrm{~N}=16$ ). The width of the central stalk also varies among specimens. In a small specimen (Fig. 2.4), the central stalk does not run through the entire length of the petalodium.

\section{Materials._Total 17 specimens.}

Remarks.-Laflamme et al. (2018) described the diverse morphologies of the central stalk in Australian Arborea specimens, including a condition in which the primary branches originate from within the boundaries of the central stalk (Laflamme et al., 2018, fig. 3.2). Dunn et al. (2019a) suggested that some of this variation is caused by composite molding of rotated branch connection points onto a cylindrical stalk. Some Shibantan specimens exhibit a similar stalk condition (e.g., Fig. 2.1). The morphological variation of the stalk could in part reflect taphonomic differences. For example, in the Australian specimens, the stalk can be sinuous when the primary branches originate from within the boundaries of the central stalk, and Laflamme et al. (2018) considered this a taphonomic artifact resulting from compression of an originally cylindrical stalk and the composite molding of alternating primary branches. However, the Shibantan specimens typically have a parallel-sided stalk and their primary branches tend to be superimposed on the stalk. It is uncertain whether the differences in stalk morphology between the Australian and Chinese specimens are biological (e.g., different degrees to which the proximal end of the primary branches encroach onto the central stalk) or taphonomic (e.g., perhaps slight rotation of the cylindrical stalk during compression). 
Some Australian Arborea specimens show a peapod-like or teardrop-like architecture of secondary branches (e.g., Laflamme et al., 2018; Dunn et al., 2019a), but these structures are not preserved in the Shibantan Arborea specimens. The presence or absence of such structures can be taphonomic variation, a dor$\mathrm{sal} / \mathrm{ventral}$ differentiation of the petalodium (i.e., peapod-like structures are enveloped by a membrane and only visible on the dorsal side; Jenkins and Gehling, 1978; Laflamme et al., 2018; Dunn et al., 2019a), or an ontogenetic variation (i.e., peapod-like structures only developed in larger, developmentally mature specimens). The Shibantan Arborea specimens are generally smaller than the Australian specimens, and their preservation is relatively poor, with no secondary branches discernable. Thus, the absence of the peapod-like structures in the Shibantan specimens is probably related to either ontogenetic or taphonomic variation.

Hofmann et al. (2008) reported Charniodiscus sp. from the Bonavista Peninsula, Newfoundland, Canada; it is very similar to Arborea arborea except that it has 14-18 primary branches, whereas Arborea arborea has $>20$ primary branches as diagnosed by Laflamme et al. (2004). However, one specimen assigned to Arborea arborea (by Dunn et al., 2019a, fig. 3A) from South Australia has only 19 primary branches. Hofmann et al. (2008) also considered possibly emending the diagnosis of Arborea arborea to accommodate specimens with $<20$ branches. This emendation is formalized here and is further supported by morphometric data described below (Fig. 3).

Results of principal component analysis (PCA) show that the first three principal components (PC) are responsible for $97.2 \%$ of the total variance observed (Table 2). PC 1 explains $\sim 80 \%$ of the total variance; the uniform and positive loadings for all variables (Table 2) suggest that it mainly reflects body size. PC 2 and PC 3 could reflect morphological variations among different species. PC 2 explains $\sim 14 \%$ of the total variance. The number of primary branches and the stalk width have the greatest positive and negative loadings, respectively, on PC 2 (Table 2). PC 3 explains $\sim 4 \%$ of the total variance. The stalk width and the largest primary branch length have large positive loadings whereas stem width has the greatest negative loading on PC3 (Table 2). Figure 3.1 and 3.2 plots all specimens in the PC $1 / 2$ and PC $2 / 3$ space, respectively. Arborea arborea from South China and South Australia share a similar morphospace as do Charniodiscus sp. and Charniodiscus arboreus from Newfoundland in these plots (Fig. 3.1, 3.2), supporting the taxonomic treatment that they all belong to the same species. This taxonomic treatment is further supported by biometric data (Table 3) and biometric plots (Fig. 3.3, width versus length of petalodium; Fig. 3.4, width versus length of the largest primary branch). In contrast, Arborea denticulata n. sp. is separated from other taxa along PC 2 and PC 3 (Fig. 3.2) and has a distinctly lower length/width ratio of the largest primary branch (Fig 3.4).

\section{Arborea denticulata new species} Figure 4

\section{Holotype.-NIGP 170067.}

Diagnosis.-Arborea with elliptical petalodium consisting of rectangular primary branches attached alternately to a central stalk at $75-90^{\circ}$. Primary branches separated from each other by distinct furrows. Petalodium attached to basal disc by a stem.

Occurrence.-Shibantan Member, Dengying Formation, Yangtze Gorges area of South China.

Description.-Holotype (Fig. 4.1, 4.2) is a bifoliate frond, 89 $\mathrm{mm}$ long (measured from the center of the basal disc to the apex), preserved as negative epirelief and positive hyporelief. The petalodium is $60 \mathrm{~mm}$ in length, $18 \mathrm{~mm}$ in width, tapers toward an apex at the distal end, and is connected to a discoidal holdfast at the basal end through a stem. Each side of the petalodium consists of at least 13 primary branches, alternately anchored to the central stalk at nearly right angles $\left(75-90^{\circ}\right)$. Primary branches are rectangular, separated from each other by transverse grooves. Primary branches are $2.9-5.8 \mathrm{~mm}$ in width (measured along the length of the stalk) and $6.0-7.9 \mathrm{~mm}$ in length (measured perpendicular to the length of the stalk), with a length/width ratio of 1.4-2.1. The largest primary branch has a length/width ratio of 1.4 and widens abaxially (away from the stalk), from $3 \mathrm{~mm}$ to $5 \mathrm{~mm}$. No discernable subdivisions of primary branches were observed. The petalodium is attached to a basal holdfast through a stem. The stem is $29 \mathrm{~mm}$ long, representing approximately one-third of the entire length of the specimen, narrows slightly toward the petalodium, and widens slightly toward the holdfast. The discoidal holdfast is $12 \mathrm{~mm}$ in diameter. It has a circular outer ridge and a central boss.

In addition to the holotype, there are two other incomplete specimens (NIGP 170068 and 173165; Fig. 4.4, 4.5) collected from the Shibantan Member. Although the stem and holdfast are not preserved in these specimens, the features of their petalodia are consistent with the diagnosis of Arborea denticulata $\mathrm{n}$. sp. Their petalodia are $25 \mathrm{~mm}$ and $106.8 \mathrm{~mm}$ long and $10 \mathrm{~mm}$ and $39.8 \mathrm{~mm}$ wide, respectively. Their largest primary branches are $3.4 \mathrm{~mm}$ and $12.3 \mathrm{~mm}$ wide (measured along the length of the stalk) and $4.8 \mathrm{~mm}$ and $19.6 \mathrm{~mm}$ long, with a length/width ratio of 1.4 and 1.6, respectively. The branching angles of primary branches emerging from the central stalk vary from $72-90^{\circ}$.

A reconstruction of Arborea denticulata n. sp. based mainly on the holotype (NIGP 170067) is presented in Figure 5.

Etymology.-From denticulata (Latin, tooth), in reference to the tooth-like rectangular shape of the primary branches.

\section{Materials.—Three specimens.}

Remarks.-Arborea denticulata $\mathrm{n}$. sp. can be distinguished from Arborea arborea by its fewer primary branches and lower length/ width ratio of the largest primary branch. The PCA analysis and biometric cross-plot (Fig. 3.2, 3.4) also show that Arborea denticulata n. sp. is distinct from Arborea arborea. Arborea denticulata n. sp. can also be distinguished from Charniodiscus yorgensis, beautifully illustrated by Ivantsov (2016), by its possession of fewer primary branches, which are rectangular in shape. In contrast with the multifoliate frond of Charniodiscus concentricus (see Dzik, 2002; Brasier and Antcliffe, 2009), Arborea denticulata $\mathrm{n}$. $\mathrm{sp}$. is bifoliate and does not display a rangeomorph-type branching pattern. The overall morphology 

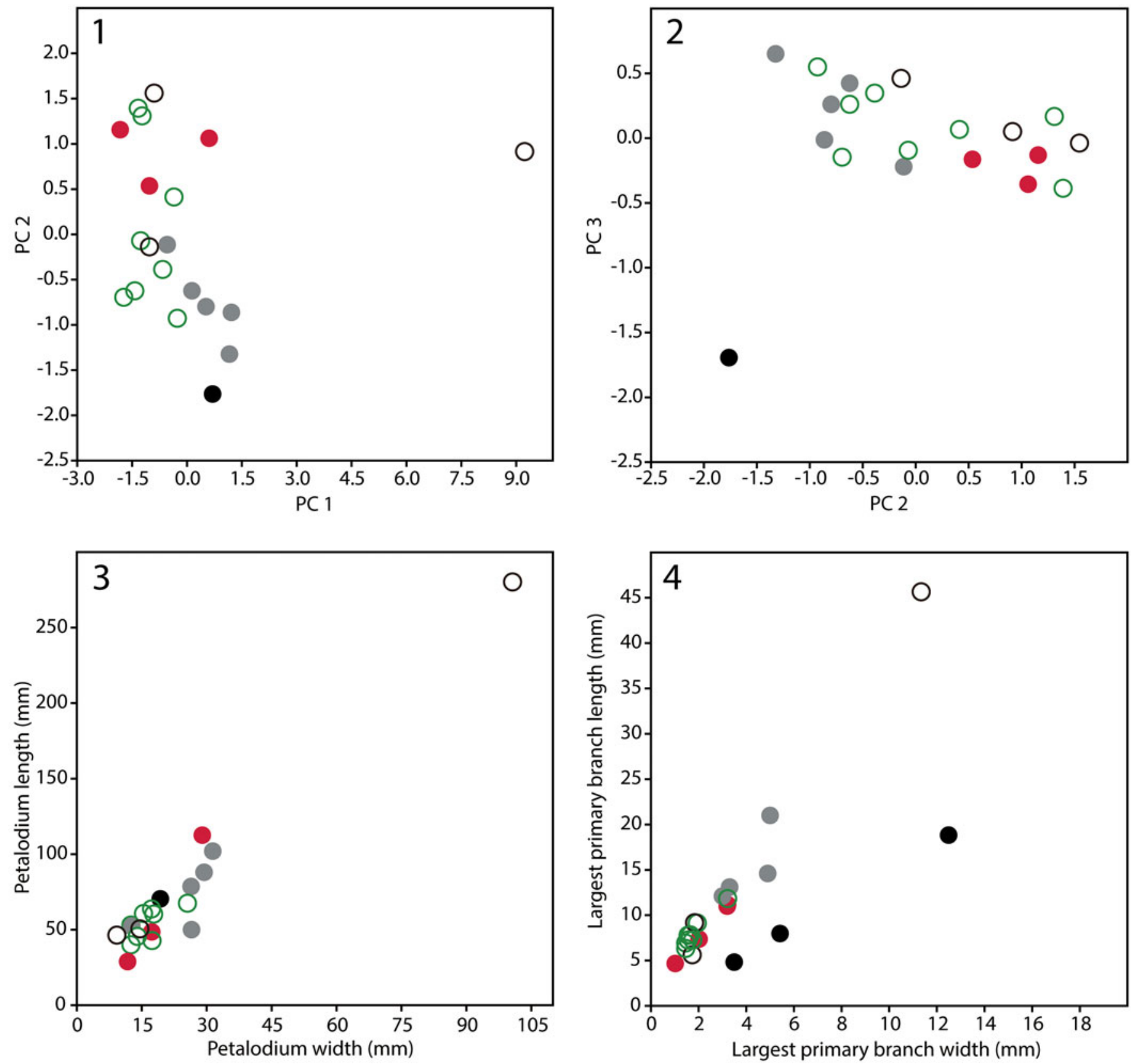

A. arborea from South Australia

A. arborea from South China

Charniodiscus sp. from Newfoundland

- Charniodiscus arboreus from Newfoundland

- A. denticulata n. sp.

Figure 3. Principal components analysis (PCA) and biometric cross-plots for Arborea arborea, Arborea denticulata n. sp., and Charniodiscus sp. of Hofmann et al. (2008): (1) PC 1 versus PC 2; the outlier to the right represents an exceptionally large specimen from South Australia; (2) PC 2 versus PC 3; Arborea denticulata n. sp. is separated from other taxa along PC 2 and PC 3 (refer to Table 2 for variable loadings and variance partition among the first three PCs); (3) cross-plot of petalodium width versus length; (4) Cross-plot of width versus length of the largest primary branch in each measured specimen; this plot includes measurements of two additional Arborea denticulata n. sp. specimens, NIGP 170068 and 173165, which are not included in PCA and (3) because their petalodia are incompletely preserved. Data sources: Arborea arborea $(\mathrm{N}=8$; this study) and Arborea denticulata $\mathrm{n}$. sp. [ $\mathrm{N}=1$ in $(\mathbf{1 - 3}), \mathrm{N}=3$ in (4); this study] from South China, Arborea arborea $(\mathrm{N}=3)$ from South Australia (Laflamme et al., 2018; Dunn et al., 2019a), Charniodiscus sp. $(\mathrm{N}=5)$ and Charniodiscus arboreus $(\mathrm{N}=3)$ from Newfoundland (Laflamme et al., 2004; Hofmann et al., 2008).

of Arborea denticulata n. sp. resembles Charniodiscus procerus in that both have $<15$ primary branches (Table 1 ). But the latter differs in that the stem occupies a greater portion (mean 39\%,
$\mathrm{N}=14$; Laflamme et al., 2004) of the entire length of the specimen, the stalk is more prominent, and diverging angles of the primary branches are more variable $\left(45-90^{\circ}\right)$. Finally, 
Table 2. Variable loadings and variance partition among the first three PCs.

\begin{tabular}{lccc}
\hline Variable & PC 1 & PC 2 & PC 3 \\
\hline Stem width & 0.3925 & -0.13402 & -0.65631 \\
Stalk width & 0.37595 & -0.27462 & 0.62286 \\
Petalodium width & 0.41862 & 0.042205 & 0.067392 \\
Petalodium length & 0.41377 & 0.04534 & -0.14336 \\
Largest primary branch width & 0.41106 & -0.11043 & -0.2123 \\
Largest primary branch length & 0.4062 & 0.045149 & 0.32937 \\
Number of branches & 0.15552 & 0.94254 & 0.051576 \\
\% variance & 79.859 & 13.804 & 3.5205 \\
\hline
\end{tabular}

Arborea denticulata $\mathrm{n}$. sp. differs from Charniodiscus spinosus in its ovate petalodium and the lack of a pronounced distal spine that is present in the latter species.

\section{Arborea sp. A}

Figure 6.1-6.4

2019 unnamed frond; Shao et al., fig. 2A-E.

Occurrence.-Shibantan Member, Dengying Formation, Yangtze Gorges area of South China.
Description.-Only one specimen is assigned to this open nomenclature. The frond is $14.3 \mathrm{~cm}$ long (measured from the center of the basal disc to the apical spine), consisting of a petalodium, a Hiemalora-like holdfast, and a connecting stem. The petalodium is elliptical, $8.2 \mathrm{~cm}$ long, $3.2 \mathrm{~cm}$ wide, composed of two rows of primary branches (Fig. 6.3). Each row consists of 6-8 primary branches. The primary branches are parallelogram-shaped, meeting alternately at a cylindrical central stalk. The branching angles are $45-90^{\circ}$. No secondary branches are preserved. The distal end of the petalodium tapers to an apical spine (Fig. 6.4). The stem is $6.1 \mathrm{~cm}$ in length, $1.3 \mathrm{~cm}$ in width, and connected to the outer rim of the holdfast. The holdfast resembles Hiemalora. The central part of the holdfast is a disc, $2.5 \mathrm{~cm}$ in diameter, flat, and without concentric rings. Approximately 27 tentacle-like appendages radiate from the outer rim of the central disc. The tentacle-like appendages are relatively uniform in width $(1.0-1.3 \mathrm{~mm}$; mean $1.2 \mathrm{~mm}, \mathrm{~N}=27)$ but vary in length $(4.9-43.8 \mathrm{~mm}$; mean $16.5 \mathrm{~mm}, \mathrm{~N}=27)$. The tentacle-like structures tend to be directed, perhaps taphonomically, toward the petalodium and they sometimes overlap each other. The rows of primary branches are preserved as negative epireliefs whereas the

Table 3. Biometric data for measured specimens. $N=$ Newfoundland; $N / A=$ not available; $S A=$ South Australia; $S C=$ South China.

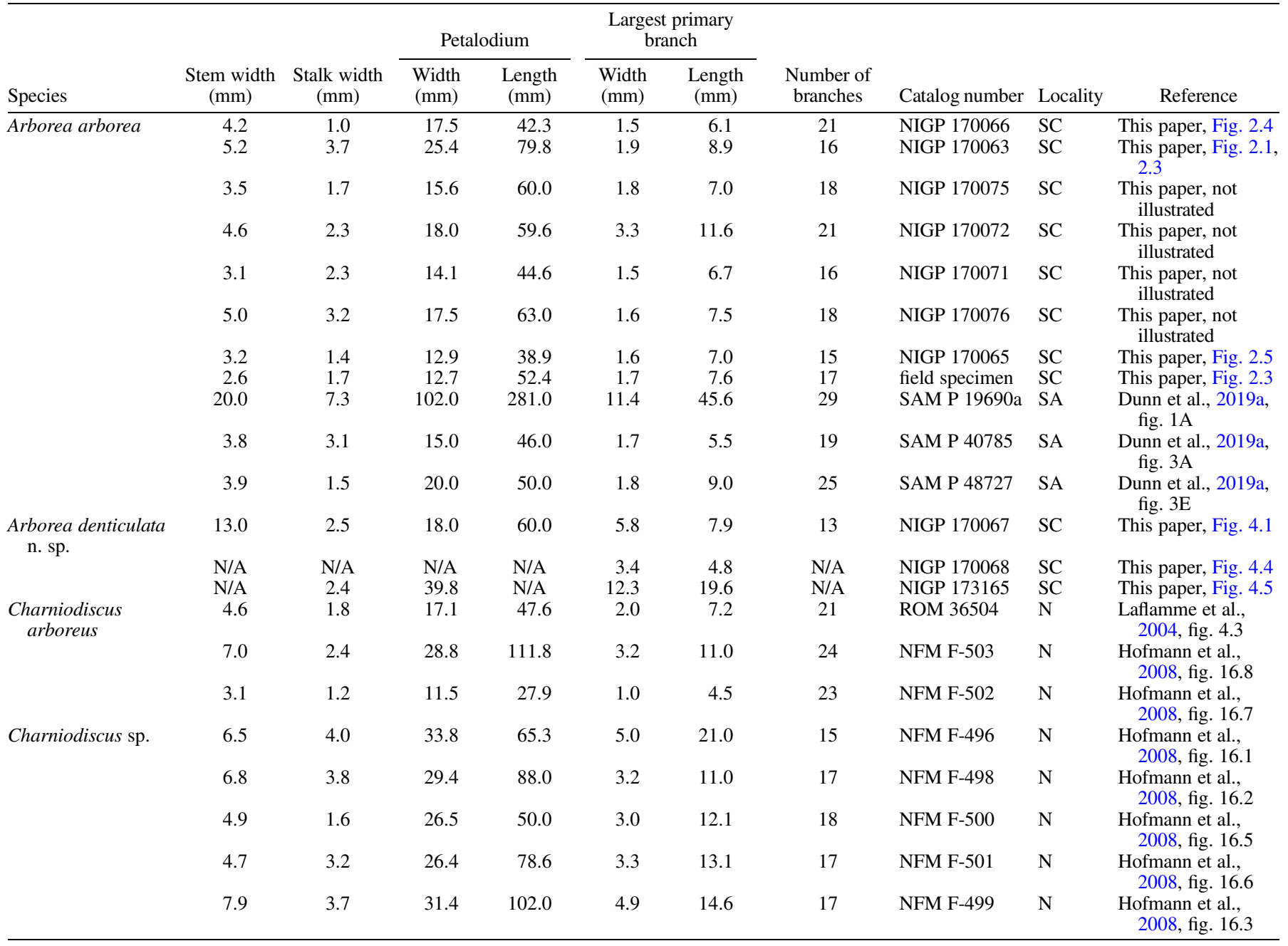



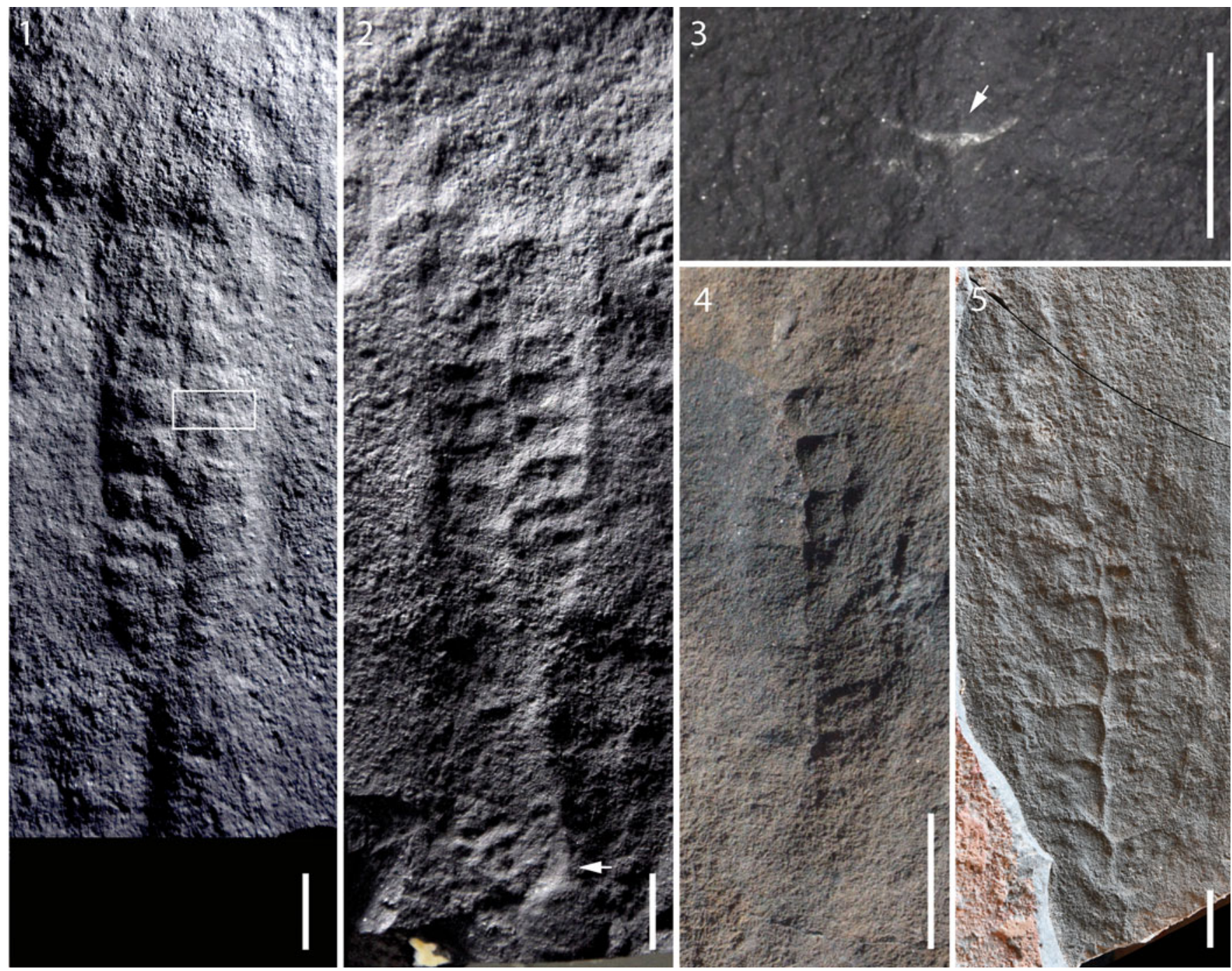

Figure 4. Arborea denticulata n. sp. from the Shibantan limestone: (1-3) holotype, NIGP 170067: (1, 2) part and counterpart, bed sole and bed top views, respectively; arrow points to where basal disc connects with stem $(\mathbf{3})$ magnified view of boxed area in (1) photographed in different lighting direction, showing shiny silvercolored carbonaceous compression of a vendotaenid fossil (arrow) directly underlying the Arborea specimen; (4) incomplete specimen, bed sole view, NIGP 170068; (5) incomplete specimen, bed sole view, NIGP 173165. Scale bars $=1 \mathrm{~cm}(\mathbf{1}, \mathbf{2}, \mathbf{4}, \mathbf{5}) ; 0.5 \mathrm{~mm} \mathrm{(3)}$.

central stalk, stem, and holdfast are preserved as positive epireliefs on the top bedding surface.

\section{Materials.-One specimen.}

Remarks.-The overall morphology of Arborea sp. A resembles Charniodiscus spinosus in petalodium shape, the number of primary branches, and the presence of an apical spine (Table 1). However, Charniodiscus spinosus exhibits a greater ratio of frond length to stem length (mean 5.77, $\mathrm{N}=28$; Laflamme et al., 2004; Table 1), whereas the ratio is 1.4 for Arborea sp. A. This difference, however, could represent either taxonomic or ecophenotypic variation (Dunn et al., 2019b). Moreover, the discoidal holdfast of Charniodiscus spinosus lacks tentacle-like structures. Kenchington and Wilby (2017) have shown that the presence/absence of tentacle-like structures in the holdfast of Ediacaran fronds could represent a species-level but not a genus-level difference, as in the case of Primocandelabrum Hofmann, O'Brien, and King, 2008.
Indeed, it is possible that Charniodiscus spinosus might need to be transferred to the genus Arborea given that the type species, Charniodiscus concentricus, is characterized by a multifoliate frond (Dzik, 2002; Brasier and Antcliffe, 2009). Because Charniodiscus spinosus and Arborea sp. A differ not only in the presence/absence of tentacle-like structures in their holdfasts (see discussion below) but also in the ratio of frond length to stem length, we are hesitant to consider these two species synonymous.

The tentacle-bearing basal disc of Arborea sp. A is morphologically indistinguishable from the discoidal fossil Hiemalora, which also occurs in the Shibantan assemblage (Chen et al., 2014; Shao et al., 2019). The Shibantan Arborea sp. A specimen provides clear evidence that an arboreomorph frond can have a Hiemalora-type holdfast. Two specimens of Charniodiscus from Newfoundland are also associated with a few filamentous structures (Liu and Dunn, 2020). The frondose fossil Primocandelabrum from the Bonavista Peninsula, Canada, possesses either a Hiemalora-type or an Aspidella-type holdfast (i.e., 


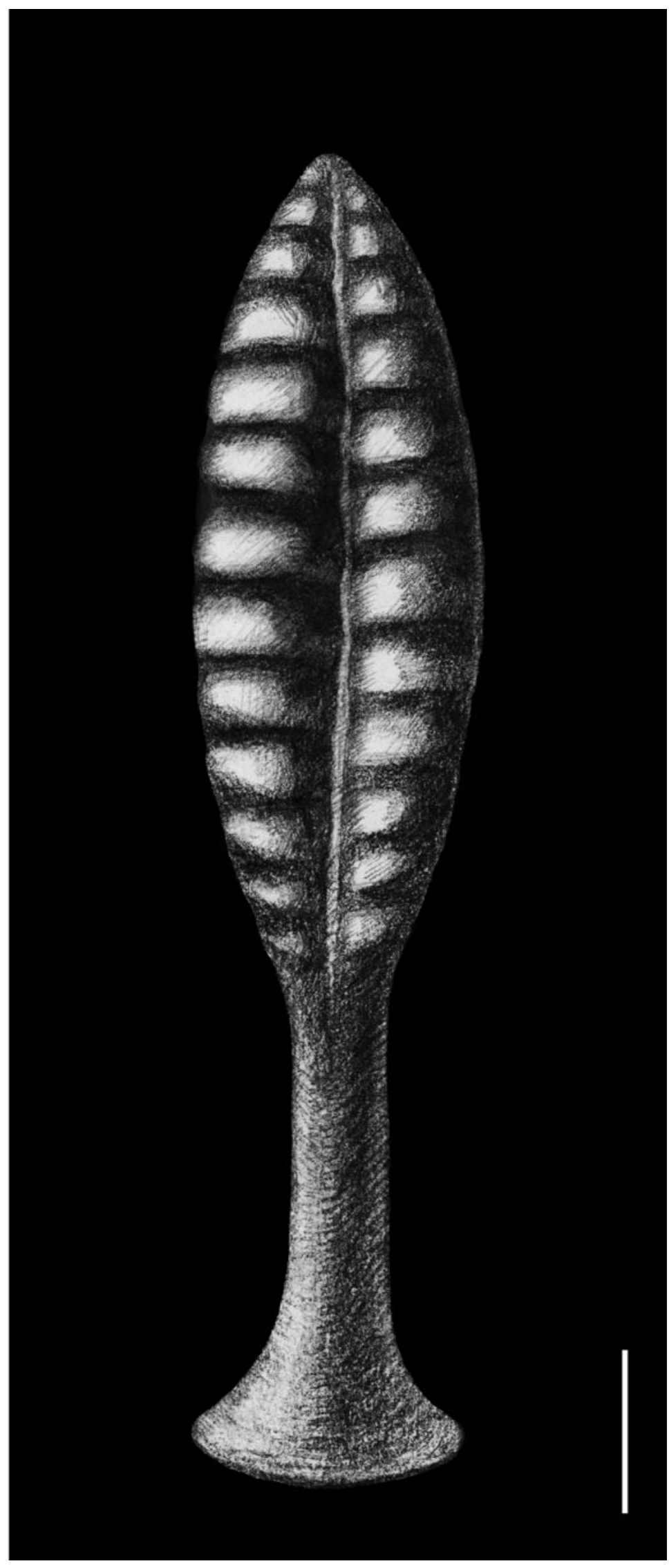

Figure 5. Reconstruction of Arborea denticulata n. sp. Scale bar $=1 \mathrm{~cm}$. 

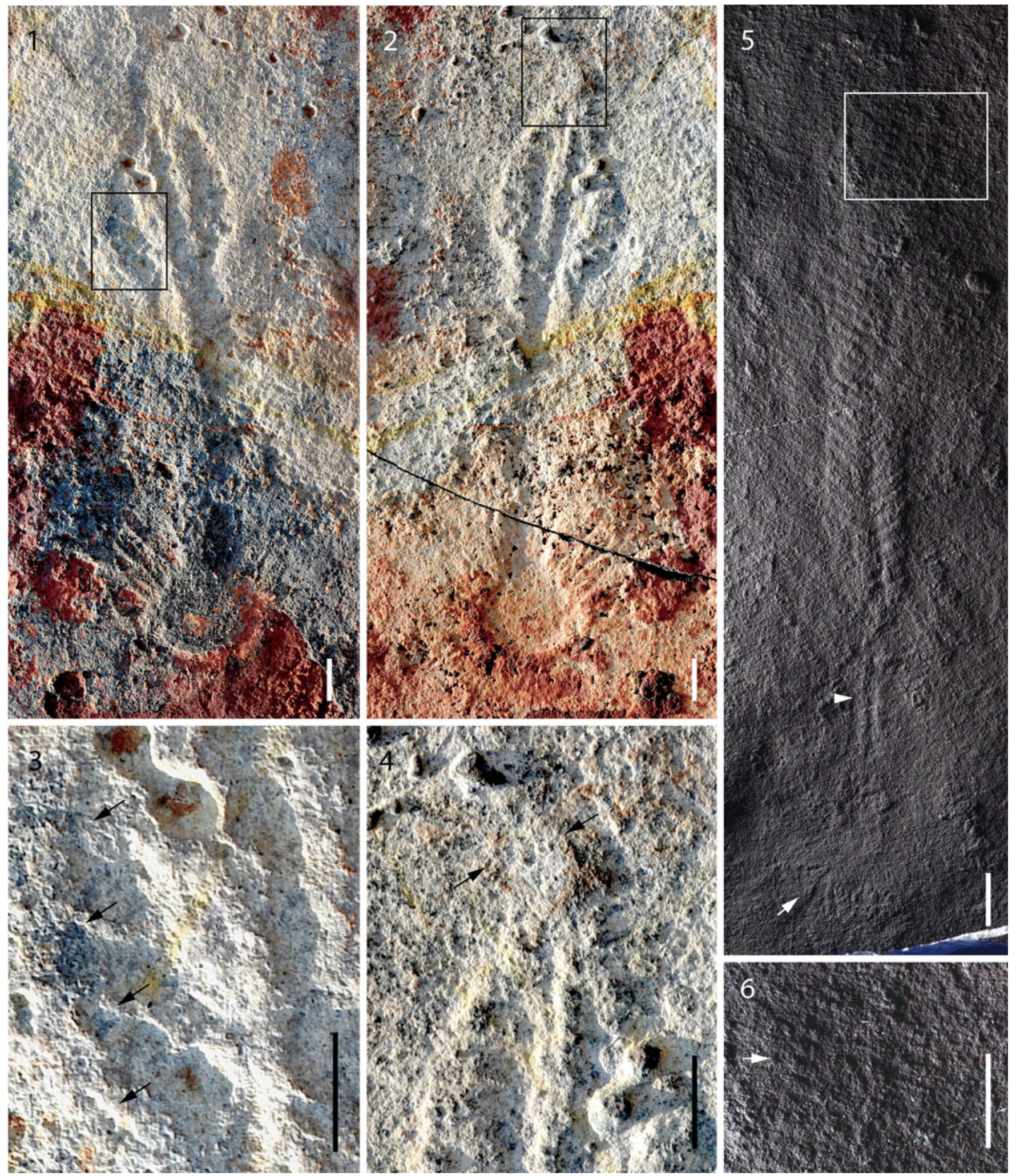

Figure 6. Arborea sp. A and Arborea sp. B from the Shibantan limestone: $(\mathbf{1}, \mathbf{2})$ part and counterpart of Arborea sp. A with a prominent tentacle-bearing Hiemaloralike basal disc, NIGP 169472: (1) negative relief on bed top; (2) positive relief on bed sole; (3) magnified view of boxed area in (1), showing primary branches (arrows); (4) magnified view of boxed area in (2), showing the apical spine (arrows); (5, 6) almost complete specimen of Arborea sp. B, bed sole view, NIGP 170064: (5) stem (arrowhead) connecting petalodium and tentacle-bearing Hiemalora-like basal disc (arrow); (6) magnified view of boxed area in (5), showing that the apical end of the petalodium is bent to the right (arrow). Scale bars $=1 \mathrm{~cm}$. 
discoidal structure without radiating tentacle-like appendages). Hofmann et al. (2008) considered the presence/absence of tentacle-like structures as the main diagnostic characteristic to distinguish Primocandelabrum hiemaloranum Hofmann, O'Brien, and King, 2008 and Primocandelabrum sp. They also commented that these two species are strikingly similar in frond morphologies but differ only in holdfast structures. The presence/absence of tentacle-like structures could reflect genuine biological features or taphomorphs because the tentacle-like appendages might not manifest on the bedding surface if they are preserved in the sediment and unexposed on the bedding surface. If Hiemalora-type and Aspidella-type basal discs are different taphomorphs of the same biological structure, as Burzynski and Narbonne (2015) suggested, it might not be appropriate to use the presence/absence of tentacle-like structures in holdfasts as a diagnostic feature for taxonomic distinction. For this reason and because there is only one specimen in our collection, we leave Arborea sp. A in open nomenclature.

\section{Arborea sp. B \\ Figure 6.5, 6.6}

Occurrence.-Shibantan Member, Dengying Formation, Yangtze Gorges area of South China.

Description.-The only specimen (Fig. 6.5) is $15.3 \mathrm{~cm}$ in length (measured from the center of the basal disc to the apex of the petalodium), $1.5 \mathrm{~cm}$ in width, and occurs as a positive hyporelief, consisting of a basal disc, a petalodium, and a connecting stem. The petalodium is elongate and nearly parallel-sided. The uppermost part of the petalodium is poorly preserved, and the remaining petalodium is $11.7 \mathrm{~cm}$ long and contains 34 primary branches on either side of the stalk. The primary branches diverge at $30-45^{\circ}$. No central stalk is present, but there is a central furrow in the lower part of the petalodium. No discernible secondary branches are observed. The basal disc is $3.5 \mathrm{~cm}$ in diameter with a faint outline. The basal disc is largely smooth, with a central boss aligned with the stem. The basal disc is attached with a ring of closely arranged tentacle-like structures up to $0.8 \mathrm{~cm}$ in length. The stem is $3.6 \mathrm{~cm}$ long and appears to have a central furrow flanked by two lateral ridges.

Materials.-One specimen.

Remarks. - The overall shape of Arborea sp. B resembles that of Arborea arborea, but it has a greater number of primary branches. Also, the petalodium of Arborea sp. B is elongated and parallel-sided, different from the ovate petalodium of Arborea arborea. Arborea sp. B also bears a large Hiemalora-like basal disc. As discussed above, because the morphology of basal discs is susceptible to preservational variation (Hofmann et al., 2008; Dunn et al., 2019a), the only specimen of Arborea sp. B is placed in open nomenclature.

\section{Taphonomy}

Ediacara-type fossils have been found in a wide range of taphonomic windows, mostly in sandstones (Sprigg, 1947), siltstones
(Grazhdankin, 2004), beneath volcanic tuffs (Narbonne, 2005), and less commonly in carbonaceous shales (Grazhdankin et al., 2008; Tang et al., 2008; Zhu et al., 2008; Xiao et al., 2013) and carbonates (Sun, 1986; Grazhdankin et al., 2008; Chen et al., 2014). The Shibantan Member in South China and the Khatyspyt Formation in Arctic Siberia represent the only two carbonate successions that are known to host morphologically complex, soft-bodied Ediacara-type macrofossils (Duda et al., 2016), although dolostone of the Gametrail Formation in northwestern Canada also contains some simple discoidal Ediacaratype macrofossils (MacNaughton et al., 2000). The Shibantan limestone hosts a moderately diverse assemblage of Ediacaran fossils, including Pteridinium, Hiemalora, Rangea, and now Arborea, as well as the tubular fossil Wutubus Chen et al., 2014, the segmented and trilobate animal Yilingia Chen et al., 2019, and abundant trace fossils (Chen et al., 2013, 2018, 2019; Meyer et al., 2014; Xiao et al., 2019).

Arborea from the late Ediacaran Shibantan limestone of South China are preserved as impressions and casts/molds. On bed tops, petaloids tend to be preserved as negative reliefs, whereas stalks and holdfasts are preserved as positive reliefs. A transverse thin section of an epirelief specimen of Arborea arborea cut perpendicular to the bedding plane illustrates this style of preservation (Fig. 7.1-7.5). The difference in relief between the stalk/holdfast and the petaloids likely reflects a combination of biological and taphonomic features: the holdfast was buried in sediment (and perhaps filled with sediment) in life, the stem and stalk might have had a greater structural integrity than the petalodium, and the petalodium might have been inflated in life and made concave impressions when it fell upon microbial mats (Fig. 7.6). Upon burial, a thin veneer of authigenic calcite was formed along the buried microbial mats, replicating the morphology of whichever side of the petalodium contacted the microbial mats (Fig. 7.7). The buried petalodium subsequently decomposed and collapsed, with sediment filling from above (Fig. 7.8).

Early diagenetic cementation to stabilize the morphology of buried carcasses prior to significant degradation is essential for the preservation of Ediacara-type macrofossils. In siliciclastic environments, this is likely achieved by the precipitation of sulfide minerals in the microbial mat that covers the buried carcasses (Gehling, 1999; Liu, 2016; Liu et al., 2019), thus forming 'death masks' of Ediacara-type organisms (Gehling, 1999). The ubiquitous microbial mats in Ediacaran benthic marine realms provided favorable loci for precipitation of iron monosulfides, fueled by microbial sulfate and iron reduction during organic degradation. These metastable iron monosulfides were transformed to pyrites during early diagenesis and molded the external features of Ediacara-type organisms. Alternatively, Tarhan et al. (2016) proposed that early diagenetic precipitation of silica, which was ultimately sourced from seawater due to the high silica content in Ediacaran oceans, might have facilitated the preservation of soft-bodied macroscopic fossils. Thin-section observations of Shibantan Arborea specimens show that calcite, rather than pyrite or silica, is associated with the fossils (Fig. 7), suggesting that authigenic calcite might have played an important taphonomic role here. Indeed, Bykova et al. (2017) independently suggested that early authigenic calcite cementation, partly facilitated by 

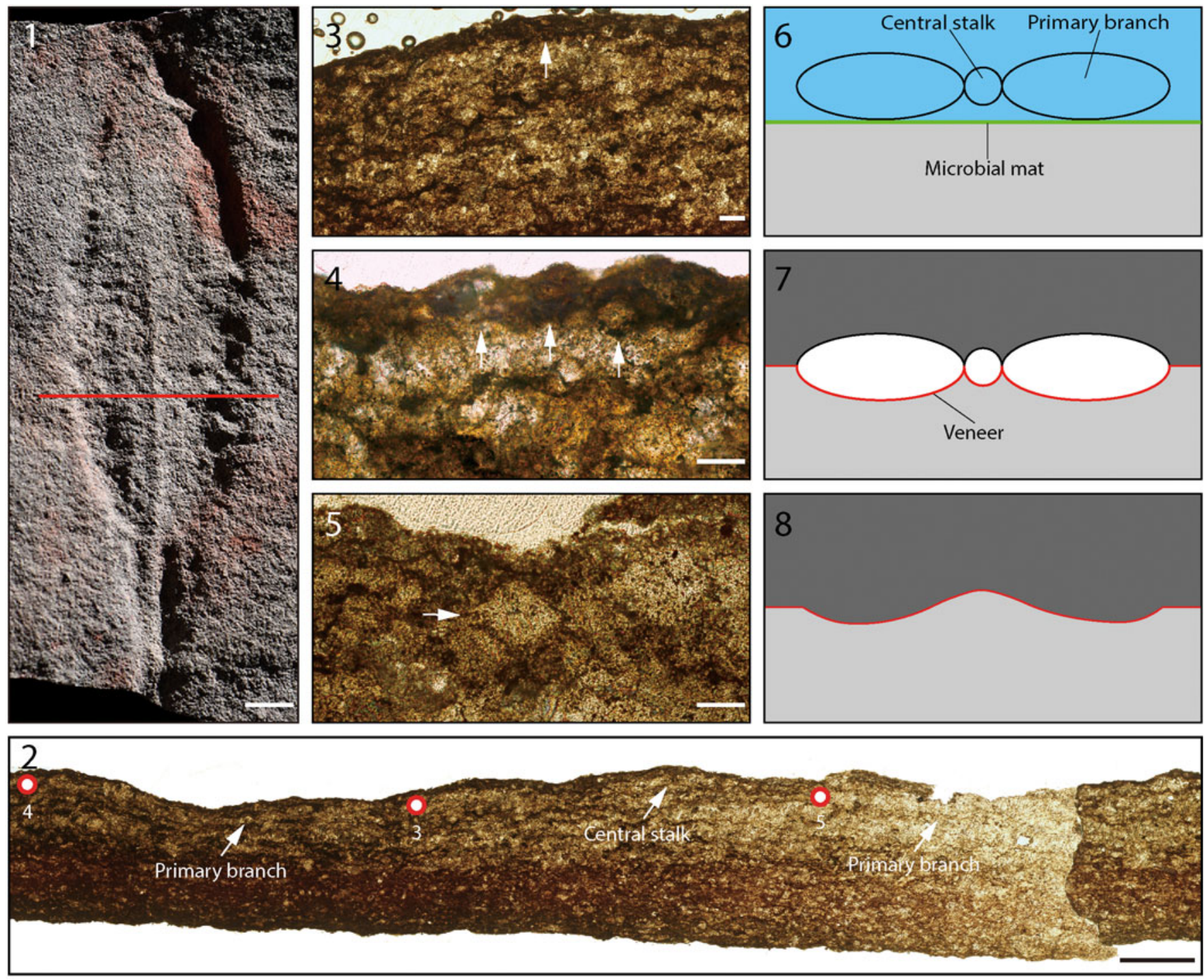

Figure 7. Petrographic observations and proposed preservation mechanism of Arborea: (1) specimen of Arborea arborea preserved on bed top; (2) transverse section cut perpendicular to bedding plane along red line in (1), in plane-polarized light, showing the central stalk and primary branches (arrows); stratigraphic up direction at top; (3-5) magnified views of labeled dots in (2): (3) possible lithified microbial mat (arrow) on fossil surface, with abundant clotted organic matter; $(\mathbf{4 , 5})$ calcite crystals (arrows) surrounded by organic matter interpreted to represent microbial mats underlying fossil surface; note abundant organic inclusions in calcite crystals; (6-8) schematic illustrations showing a proposed model of Arborea preservation: $(\mathbf{6})$ transverse sectional view of Arborea before burial (blue $=$ seawater; green = microbial mat; gray = sediment); (7) early stage of burial, with a carbonate veneer formed rapidly along the former microbial mat surface (red curve), which replicated the morphology of Arborea in contact with mat surface; (8) organism collapsed due to decomposition and compaction, with its lower surface (side in contact with microbial mat) preserved as a positive hyporelief. Scale bars $=5 \mathrm{~mm} \mathrm{(1);1} \mathrm{mm}(\mathbf{2}) ; 20 \mu \mathrm{m} \mathrm{(3-5)}$.

masking microbial mats, might have fulfilled the role of casting and molding the morphologies of Ediacara-type fossils, e.g., Aspidella Billings, 1872, preserved in carbonate facies of the Khatyspyt Formation in Arctic Siberia.

Like the Khatyspyt specimens, traces of microbial mats as evidenced by dark organic laminae are often associated with the fossil surface of Arborea preserved in the Shibantan limestone (Fig. 7.2, 7.3). Within the putative microbial mats, organic matter forms clots and anastomosing stringers around carbonate minerals, which are also cloudy and full of organic inclusions, typical of authigenic minerals precipitated in degrading microbial mats (Flügel, 2010; Chen et al., 2013, 2014; Meyer et al., 2014). In modern microbial mats, cyanobacteria and other microbes produce exopolymeric substances (EPS), which inhibit precipitation of calcium carbonate by absorbing $\mathrm{Ca}^{2+}$ (e.g., Dupraz and Visscher, 2005; Glunk et al., 2011; Pace et al., 2018). Immediately beneath the cyanobacterial mat, a large amount of calcium carbonate precipitation initiates where degradation of EPS occurs. Low-molecular-weight organic carbon as well as EPS are broken down by sulfate-reducing microbes, liberating $\mathrm{Ca}^{2+}$ and increasing alkalinity. The zone of microbial sulfate reduction, which could be very shallow and only $2-5 \mathrm{~mm}$ deep from the mat surface (e.g., Visscher et al., 2000; Glunk et al., 2011), is where carbonate precipitation occurs. A similar carbonate precipitation mechanism may have also played an important role in stabilizing the mat surfaces, hence facilitating the preservation of Arborea fossils in the Shibantan limestone. 
Sun (1986) noted that the Ediacaran fossil Paracharnia Sun, 1986 from the Shibantan Member is closely associated with vendotaenid macroalgal remains. Abundant vendotaenids are also present on the slab of the holotype of Arborea denticulata $\mathrm{n}$. sp. and some of them are directly associated with specimens of Arborea denticulata n. sp. (Fig 4.3). Intriguingly, vendotaenids are typically preserved as carbonaceous films perhaps surrounded by authigenic minerals, e.g., clays and pyrites (Anderson et al., 2011), whereas Arborea denticulata n. sp. is preserved as casts and molds. The co-existence of two different types of preservation in the same slab is intriguing. We speculate that biological, ecological, and stratinomic differences could have led to different preservation modes in vendotaenids and Arborea denticulata n. sp. For example, vendotaenids are traditionally interpreted as thin planktonic thalli that are unlikely to make concave impressions on sediment surface, whereas Arborea denticulata $\mathrm{n}$. sp. was a benthic macro-organism with a three dimensionality that allowed cast-and-mold preservation. Additionally, different tissue types between vendotaenids (possibly algae) and Arborea denticulata $\mathrm{n}$. sp. (probably a total-group metazoan) might have also contributed to their different preservational modes.

\section{Conclusion}

This report augments our knowledge about Ediacaran frondose fossils by illustrating four taxa of Arborea (Arborea arborea, Arborea denticulata n. sp., Arborea sp. A, and Arborea sp. B) from the terminal Ediacaran Shibantan limestone in the Yangtze Gorges area of South China. Arborea arborea is the most abundant among the four taxa. Arborea denticulata n. sp. resembles Arborea arborea in general morphology but differs in possessing fewer primary branches that are rectangular in shape, as well as a lower length/width ratio of its primary branches. Arborea sp. A and Arborea sp. B are fronds with a Hiemaloratype basal attachment.

Microbial mats and early diagenetic precipitation of carbonate minerals might have facilitated the preservation of Arborea in the Shibantan limestone. The co-existence of Ediacaran fronds (preserved as casts and molds) and vendotaenids (preserved as carbonaceous films, perhaps surrounded by authigenic minerals) testifies the taphonomic diversity in the Shibantan Member.

\section{Acknowledgments}

This research was supported by the Chinese Academy of Sciences (QYZDJ-SSW-DQC009, XDB26000000, and XDB18000000), the National Natural Science Foundation of China (41921002 and 41602007), the Chinese Ministry of Science and Technology (2017YFC0603100), the Science Foundation of Jiangsu Province of China (BK20161090), and the State Key Laboratory of Palaeobiology and Stratigraphy (20201102). SX was supported by the U.S. National Science Foundation (EAR-2021207). The paper has benefitted from discussions with Y. Shao. Figure 5 was drawn by Y. Du. We thank Associate Editor A. Liu, G. Narbonne, and M. Laflamme for constructive reviews.

\section{References}

Anderson, E.P., Schiffbauer, J.D., and Xiao, S., 2011, Taphonomic study of Ediacaran organic-walled fossils confirms the importance of clay minerals and pyrite in Burgess Shale-type preservation: Geology, v. 39, p. 643646, doi:10.1130/G31969.1.

Billings, E., 1872, On some fossils from the primordial rocks of Newfoundland: Canadian Naturalist and Quarterly Journal of Science, v. 6, p. 465-479.

Boag, T.H., Darroch, S.A.F., and Laflamme, M., 2016, Ediacaran distributions in space and time: Testing assemblage concepts of earliest macroscopic body fossils: Paleobiology, v. 42, p. 574-594, doi:10.1017/pab.2016.20.

Borchvardt, D.V., and Nessov, L.A., 1999, New records of metaphytes from the Vendian (Precambrian) of Zimnii Bereg of the White Sea: Trudy Zoologicheskogo Instituta Rossiǐskoĭ Akademii Nauk, v. 277, p. 50-57. [in Russian]

Brasier, M.D., and Antcliffe, J.B., 2009, Evolutionary relationships within the Avalonian Ediacara biota: New insights from laser analysis: Journal of the Geological Society, v. 166, p. 363-384, doi:10.1144/0016-76492008-011.

Budd, G.E., and Jensen, S., 2015, The origin of the animals and a 'Savannah' hypothesis for early bilaterian evolution: Biological Reviews, v. 92, p. 446-473, doi:10.1111/brv.12239.

Burzynski, G., and Narbonne, G.M., 2015, The discs of Avalon: Relating discoid fossils to frondose organisms in the Ediacaran of Newfoundland, Canada: Palaeogeography, Palaeoclimatology, Palaeoecology, v. 434, p. 34-45, doi:10.1016/j.palaeo.2015.01.014.

Bykova, N., Gill, B.C., Grazhdankin, D., Rogov, V., and Xiao, S., 2017, A geochemical study of the Ediacaran discoidal fossil Aspidella preserved in limestones: Implications for its taphonomy and paleoecology: Geobiology, v. 15 , p. 572-587, doi:10.1111/gbi.12240.

Callow, R.H.T., and Brasier, M.D., 2009, Remarkable preservation of microbial mats in Neoproterozoic siliciclastic settings: Implications for Ediacaran taphonomic models: Earth-Science Reviews, v. 96, p. 207-219, doi:10.1016/j.earscirev.2009.07.002.

Cao, R., Tang, T., Xue, Y., Yu, C., Yin, L., and Zhao, W., 1989, Research on Sinian Strata with ore deposits in the Yangzi (Yangtze) region, China, in Nanjing Institute of Geology and Palaeontology, ed., Upper Precambrian of the Yangzi (Yangtze) Region, China: Nanjing, China, Nanjing University Press, p. 1-94. [in Chinese with English summary]

Chen, Z., Zhou, C., Meyer, M., Xiang, K., Schiffbauer, J.D., Yuan, X., and Xiao, S., 2013, Trace fossil evidence for Ediacaran bilaterian animals with complex behaviors: Precambrian Research, v. 224, p. 690-701, doi:10.1016/ j.precamres.2012.11.004.

Chen, Z., Zhou, C., Xiao, S., Wang, W., Guan, C., Hua, H., and Yuan, X., 2014, New Ediacara fossils preserved in marine limestone and their ecological implications: Scientific Reports, v. 4, p. 4108, doi:10.1038/srep04180.

Chen, Z., Chen, X., Zhou, C., Yuan, X., and Xiao, S., 2018, Late Ediacaran trackways produced by bilaterian animals with paired appendages: Science Advances, v. 4, p. eaao6691, doi:10.1126/sciadv.aao6691.

Chen, Z., Zhou, C., Yuan, X., and Xiao, S., 2019, Death march of a segmented and trilobate bilaterian elucidates early animal evolution: Nature, v. 573 p. 412-415, doi:10.1038/s41586-019-1522-7.

Condon, D., Zhu, M., Bowring, S., Wang, W., Yang, A., and Jin, Y., 2005, U-Pb ages from the Neoproterozoic Doushantuo Formation, China: Science, v. 308, p. 95-98, doi:10.1126/science. 1107765.

Dececchi, T.A., Narbonne, G.M., Greentree, C., and Laflamme, M., 2017, Relating Ediacaran fronds: Paleobiology, v. 43, p. 171-180, doi:10.1017/pab.2016.54

Dececchi, T.A., Narbonne, G.M., Greentree, C., and Laflamme, M., 2018, Phylogenetic relationships among the Rangeomorpha: The importance of outgroup selection and implications for their diversification: Canadian Journal of Earth Sciences, v. 55, p. 1223-1239, doi:10.1139/cjes-2018-0022.

Droser, M.L., Tarhan, L.G., and Gehling, J.G., 2017, The rise of animals in a changing environment: Global ecological innovation in the late Ediacaran: Annual Review of Earth and Planetary Sciences, v. 45, p. 593-617, doi:10.1146/annurev-earth-063015-015645.

Duda, J.-P., Zhu, M., and Reitner, J., 2016, Depositional dynamics of a bituminous carbonate facies in a tectonically induced intra-platform basin: The Shibantan Member (Dengying Formation, Ediacaran Period): Carbonates and Evaporites, v. 31, p. 87-99, doi:10.1007/s13146-015-0243-8.

Dunn, F.S., Liu, A.G., and Donoghue, P.C.J., 2018, Ediacaran developmental biology: Biological Reviews, v. 93, p. 914-932, doi:10.1111/brv.12379.

Dunn, F.S., Liu, A.G., and Gehling, J., 2019a, Anatomical and ontogenetic reassessment of the Ediacaran frond Arborea arborea and its placement within total group Eumetazoa: Palaeontology, v. 62, p. 851-865, doi:10.1111/pala.12431.

Dunn, F.S., Wilby, P.R., Kenchington, C.G., Grazhdankin, D.V., Donoghue, P.C., and Liu, A.G., 2019b, Anatomy of the Ediacaran rangeomorph Charnia masoni: Papers in Palaeontology, v. 5, p. 157-176, doi:10.1002/spp2.1234.

Dupraz, C., and Visscher, P.T., 2005, Microbial lithification in marine stromatolites and hypersaline mats: Trends in Microbiology, v. 13, p. 429-438, doi:10.1016/j.tim.2005.07.008. 
Dzik, J., 2002, Possible ctenophoran affinities of the Precambrian 'sea-pen' Rangea: Journal of Morphology, v. 252, p. 315-334, doi:10.1002/jmor.1108.

Erwin, D.H., Laflamme, M., Tweedt, S.M., Sperling, E.A., Pisani, D., and Peterson, K.J., 2011, The Cambrian conundrum: Early divergence and later ecological success in the early history of animals: Science, v. 334, p. 10911097, doi:10.1126/science.1206375.

Fedonkin, M.A., 1982, A new generic name for some Precambrian coelenterates: Paleontological Journal, v. 16, p. 127

Fedonkin, M.A., 1985, Systematic description of Vendian Metazoa, in Sokolov, B.S. and Ivanovskiy, A.B., eds., The Vendian System: Historic-Geological and Palaeontological Basis, Volume 1, Paleontology: Moscow, Nauka, p. 70-107.

Flügel, E., 2010, Microfacies of Carbonate Rocks (second edition): Berlin, Springer, $984 \mathrm{p}$

Ford, T.D., 1958, Pre-cambrian fossils from Charnwood Forest: Proceedings of the Yorkshire Geological Society, v. 31, p. 211-217.

Gehling, J.G., 1999, Microbial mats in terminal Proterozoic siliciclastics: Ediacaran death masks: Palaios, v. 14, p. 40-57, doi:10.2307/3515360.

Gehling, J.G., and Droser, M.L., 2013, How well do fossil assemblages of the Ediacara biota tell time?: Geology, v. 41, p. 447-450, doi:10.1130/G33881.1.

Gehling, J.G., and Narbonne, G.M., 2007, Spindle-shaped Ediacara fossils from the Mistaken Point assemblage, Avalon zone, Newfoundland: Canadian Journal of Earth Sciences, v. 44, p. 367-387, doi:10.1139/e07-003.

Glaessner, M.F., 1979, Biogeography and biostratigraphy: Precambrian, in Moore, R.C., Robinson, R.A., and Teichert, C., eds., Treatise on Invertebrate Paleontology, Part A, Introduction, Fossilization (Taphonomy), Biogeography and Biostratigraphy: Boulder, Colorado and Lawrence, Kansas, Geological Society of America (and University of Kansas Press), p. A79-A118.

Glaessner, M.F., and Daily, B., 1959, The geology and late Precambrian fauna of the Ediacara fossil reserve: Records of the South Australian Museum, v. 13 , p. $369-401$

Glaessner, M.F., and Wade, M., 1966, The late Precambrian fossils from Ediacara, South Australia: Palaeontology, v. 9, p. 599-628.

Glunk, C., Dupraz, C., Braissant, O., Gallagher, K.L., Verrecchia, E.P., and Visscher, P.T., 2011, Microbially mediated carbonate precipitation in a hypersaline lake, Big Pond (Eleuthera, Bahamas): Sedimentology, v. 58, p. 720-736, doi:10.1111/j.1365-3091.2010.01180.x.

Gnilovskaya, M.B., 1971, The most ancient Vendian water plants on the Russian platform: Paleontological Journal, v. 3, p. 101-107. [in Russian]

Grazhdankin, D., 2014, Patterns of evolution of the Ediacaran soft-bodied biota: Journal of Paleontology, v. 88, p. 269-283, doi:10.1666/13-072.

Grazhdankin, D.V., 2004, Patterns of distribution in the Ediacaran biotas: Facies versus biogeography and evolution: Paleobiology, v. 30, p. 203-221, doi:10.1666/0094-8373(2004)030<0203:PODITE > 2.0.CO;2.

Grazhdankin, D.V., Balthasar, U., Nagovitsin, K.E., and Kochnev, B.B., 2008, Carbonate-hosted Avalon-type fossils in Arctic Siberia: Geology, v. 36, p. 803-806, doi:10.1130/G24946A.1.

Gürich, G., 1929, Die ältesten Fossilien Südafrikas: Zeitschrift praktische Geologie mit besonderer Berücksichtigung der Lagerstättenkunde, v. 37, p. 85. [in German]

Gürich, G., 1930, Über der Kuibis-Quarzit in Südwestafrika: Zeitschrift der Deutschen Geologischen Gesellschaft, v. 82, p. 637. [in German]

Hammer, Ø., Harper, D.A.T., and Ryan, P.D., 2001, PAST: Paleontological statistics software package for education and data analysis: Palaeontologia Electronica, v. 4, p. 9

Hofmann, H.J., O'Brien, S.J., and King, A.F., 2008, Ediacaran biota on Bonavista Peninsula, Newfoundland, Canada: Journal of Paleontology, v. 82, p. 1-36, doi:10.1666/06-087.1.

Hoyal Cuthill, J.F., and Conway Morris, S., 2014, Fractal branching organizations of Ediacaran rangeomorph fronds reveal a lost Proterozoic body plan: Proceedings of the National Academy of Sciences of the United States of America, v. 111, p. 13122-13126, doi:10.1073/pnas.1408542111.

Hoyal Cuthill, J.F., and Han, J., 2018, Cambrian petalonamid Stromatoveris phylogenetically links Ediacaran biota to later animals: Palaeontology, v. 61, p. 813-823, doi:10.1111/pala.12393.

Ivantsov, A.Y., 2016, Reconstruction of Charniodiscus yorgensis (Macrobiota from the Vendian of the White Sea): Paleontological Journal, v. 50, p. 112, doi:10.1134/S0031030116010032.

Jenkins, R.J.F., 1996, Aspects of the geological setting and palaeobiology of the Ediacara assemblage, in Davies, M., Twidale, C.R., and Tyler, M.J., eds., Natural History of the Flinders Ranges: Richmond, South Australia, Royal Society of South Australia, v. 7, p. 33-45.

Jenkins, R.J.F., and Gehling, J.G., 1978, A review of the frond-like fossils of the Ediacara assemblage: Records of the South Australian Museum, v. 17, p. 347-359

Kenchington, C.G., and Wilby, P.R., 2017, Rangeomorph classification schemes and intra-specific variation: Are all characters created equal?: Geological Society, London, Special Publications, v. 448, p. 221-250, doi:10.1144/SP448.19.
Laflamme, M., and Narbonne, G.M., 2008, Ediacaran fronds: Palaeogeography, Palaeoclimatology, Palaeoecology, v. 258, p. 162-179, doi:10.1016/ j.palaeo.2007.05.020.

Laflamme, M., Narbonne, G.M., and Anderson, M.M., 2004, Morphometric analysis of the Ediacaran frond Charniodiscus from the Mistaken Point Formation, Newfoundland: Journal of Paleontology, v. 78, p. 827-837, doi:10.1666/0022-3360(2004)078<0827:MAOTEF>2.0.CO;2.

Laflamme, M., Xiao, S., and Kowalewski, M., 2009, Osmotrophy in modular Ediacara organisms: Proceedings of the National Academy of Sciences, v. 106, p. 14438-14443, doi:10.1073/pnas.0904836106.

Laflamme, M., Schiffbauer, J.D., Narbonne, G.M., and Briggs, D.E.G., 2011, Microbial biofilms and the preservation of the Ediacara biota: Lethaia, v. 44 p. 203-213, doi:10.1111/j.1502-3931.2010.00235.x.

Laflamme, M., Gehling, J.G., and Droser, M.L., 2018, Deconstructing an Ediacaran frond: Three-dimensional preservation of Arborea from Ediacara, South Australia: Journal of Paleontology, v. 92, p. 323-335, doi:10.1017/ jpa.2017.128

Linnemann, U., Ovtcharova, M., Schaltegger, U., Gärtner, A., Hautmann, M. Geyer, G., Vickers-Rich, P., Rich, T., Plessen, B., Hofmann, M., Zieger, J., Krause, R., Kriesfeld, L., and Smith, J., 2019, New high-resolution age data from the Ediacaran-Cambrian boundary indicate rapid, ecologically driven onset of the Cambrian explosion: Terra Nova, v. 31, p. 49-58, doi:10.1111/ter.12368.

Liu, A.G., 2016, Framboidal pyrite shroud confirms the 'death mask' model for moldic preservation of Ediacaran soft-bodied organisms: Palaios, v. 31, p. 259-274, doi:10.2110/palo.2015.095.

Liu, A.G., and Dunn, F.S., 2020, Filamentous connections between Ediacaran fronds: Current Biology, v. 30, p. 1322-1328.e3, doi:10.1016/ j.cub.2020.01.052.

Liu, A.G., McMahon, S., Matthews, J.J., Still, J.W., and Brasier, A.T., 2019, Petrological evidence supports the death mask model for the preservation of Ediacaran soft-bodied organisms in South Australia: Geology, v. 47, p. 215-218, doi:10.1130/G45918.1.

MacNaughton, R.B., Narbonne, G.M., and Dalrymple, R.W., 2000, Neoproterozoic slope deposits, Mackenzie Mountains, northwestern Canada: Implications for passive-margin development and Ediacaran faunal ecology: Canadian Journal of Earth Sciences, v. 37, p. 997-1020, doi:10.1139/ cjes-37-7-997.

Meyer, M., Xiao, S., Gill, B.C., Schiffbauer, J.D., Chen, Z., Zhou, C., and Yuan, X., 2014, Interactions between Ediacaran animals and microbial mats: Insights from Lamonte trevallis, a new trace fossil from the Dengying Formation of South China: Palaeogeography, Palaeoclimatology, Palaeoecology, v. 396 , p. 62-74, doi:10.1016/j.palaeo.2013.12.026

Narbonne, G.M., 2005, The Ediacara biota: Neoproterozoic origin of animals and their ecosystems: Annual Review of Earth and Planetary Sciences, v. 33, p. 421-442, doi:10.1146/annurev.earth.33.092203.122519.

O'Brien, S.J., and King, A.F., 2004, Ediacaran fossils from the Bonavista Peninsula (Avalon Zone), Newfoundland: Preliminary descriptions and implications for regional correlation: Newfoundland Department of Mines and Energy, Geological Survey, Report 04-01, p. 203-212.

Pace, A., Bourillot, R., Bouton, A., Vennin, E., Braissant, O., Dupraz, C., Duteil, T., Bundeleva, I., Patrier, P., Galaup, S., Yokoyama, Y., Franceschi, M., Virgone, A., and Visscher, P.T., 2018, Formation of stromatolite lamina at the interface of oxygenic-anoxygenic photosynthesis: Geobiology, v. 16, p. 378-398, doi:10.1111/gbi.12281.

Peterson, K.J., Waggoner, B., and Hagadorn, J.W., 2003, A fungal analog for Newfoundland Ediacaran fossils?: Integrative and Comparative Biology, v. 43, p. 127-136, doi:10.1093/icb/43.1.127.

Pu, J.P., Bowring, S.A., Ramezani, J., Myrow, P., Raub, T.D., Landing, E., Mills A., Hodgin, E., and Macdonald, F.A., 2016, Dodging snowballs: Geochronology of the Gaskiers glaciation and the first appearance of the Ediacaran biota: Geology, v. 44, p. 955-958, doi:10.1130/G38284.1.

Retallack, G.J., 1994, Were the Ediacaran fossils lichens?: Paleobiology, v. 20, p. 523-544, doi:10.1017/S0094837300012975.

Schmitz, M.D., 2012, Appendix 2, Radiometric ages used in GTS2012, in Gradstein, F.M., Ogg, J.G., Schmitz, M.D., and Ogg, G.M., eds., The Geological Time Scale 2012, 2 Volumes: Boston, Elsevier, p. 1045-1082.

Seilacher, A., 1984, Late Precambrian and early Cambrian Metazoa: Preservational or real extinctions?, in Holland, H.D., and Trendall, A.F., eds., Patterns of Change in Earth Evolution: Berlin, Springer-Verlag, p. $159-168$

Shao, Y., Chen, Z., Zhou, C., and Yuan, X., 2019, Hiemalora stellaris from the Ediacaran Dengying Formation in the Yangtze Gorges area, Hubei Province: Affinity and taphonomic analysis: Acta Palaeontologica Sinica v. 58, p. 1-10, doi:10.19800/j.cnki.aps.2019.01.001 [in Chinese with English summary].

Shen, B., Xiao, S., Zhou, C., and Yuan, X., 2009, Yangtziramulus zhangi new genus and species, a carbonate-hosted macrofossil from the Ediacaran 
Dengying Formation in the Yangtze Gorges area, South China: Journal of Paleontology, v. 83, p. 575-587, doi:10.1666/08-042R1.1.

Shen, B., Xiao, S., Zhou, C., Dong, L., Chang, J., and Chen, Z., 2017, A new modular palaeopascichnid fossil Curviacus ediacaranus new genus and species from the Ediacaran Dengying Formation in the Yangtze Gorges area of South China: Geological Magazine, v. 154, p. 1257-1268, doi:10.1017/ S001675681700036X

Shu, D., Morris, S.C., Han, J., Li, Y., Zhang, X., Hua, H., Zhang, Z., Liu, J., Guo, J., Yao, Y., and Yasui, K., 2006, Lower Cambrian vendobionts from China and early diploblast evolution: Science, v. 312, p. 731-734, doi:10.1126/ science. 1124565 .

Sprigg, R.C., 1947, Early Cambrian (?) jellyfishes from the Flinders Ranges, South Australia: Transactions of the Royal Society of South Australia, v. 71, p. $212-224$.

Sun, W., 1986, Late Precambrian pennatulids (sea pens) from the eastern Yangtze Gorge, China: Paracharnia gen. nov.: Precambrian Research, v. 31 , p. 361-375, doi:10.1016/0301-9268(86)90040-9.

Tang, F., Yin, C., Bengtson, S., Liu, P., Wang, Z., and Gao, L., 2008, Octoradiate spiral organisms in the Ediacaran of South China: Acta Geologica Sinica, v. 82 , p. $27-34$, doi:10.1111/j.1755-6724.2008.tb00321.x.

Tarhan, L.G., Hood, A.v.S., Droser, M.L., Gehling, J.G., and Briggs, D.E.G., 2016, Exceptional preservation of soft-bodied Ediacara biota promoted by silica-rich oceans: Geology, v. 44, p. 951-954, doi:10.1130/G38542.1.

Visscher, P.T., Reid, R.P., and Bebout, B.M., 2000, Microscale observations of sulfate reduction: Correlation of microbial activity with lithified micritic laminae in modern marine stromatolites: Geology, v. 28, p. 919-922, doi:10.1130/0091-7613(2000)28 < 919:MOOSRC > 2.0.CO;2.

Waggoner, B., 1999, Biogeographic analyses of the Ediacara biota: A conflict with paleotectonic reconstructions: Paleobiology, v. 25 , p. 440-458, doi:10.1017/S0094837300020315.

Weber, B., Steiner, M., and Zhu, M., 2007, Precambrian-Cambrian trace fossils from the Yangtze Platform (South China) and the early evolution of bilaterian lifestyles: Palaeogeography, Palaeoclimatology, Palaeoecology, v. 254, p. 328-349, doi:10.1016/j.palaeo.2007.03.021.
Wood, D.A., Dalrymple, R.W., Narbonne, G.M., Gehling, J.G., and Clapham, M.E., 2003, Paleoenvironmental analysis of the late Neoproterozoic Mistaken Point and Trepassey formations, southeastern Newfoundland: Canadian Journal of Earth Sciences, v. 40, p. 1375-1391, doi:10.1139/e03-048.

Xiao, Q., She, Z., Wang, G., Li, Y., Ouyang, G., Cao, K., Mason, R., and Du, Y., 2020, Terminal Ediacaran carbonate tempestites in the eastern Yangtze Gorges area, South China: Palaeogeography, Palaeoclimatology, Palaeoecology, v. 547, p. 109681, doi:10.1016/j.palaeo.2020.109681.

Xiao, S., and Laflamme, M., 2009, On the eve of animal radiation: Phylogeny, ecology and evolution of the Ediacara biota: Trends in Ecology \& Evolution, v. 24, p. 31-40, doi:10.1016/j.tre.2008.07.015.

Xiao, S., Shen, B., Zhou, C., Xie, G., and Yuan, X., 2005, A uniquely preserved Ediacaran fossil with direct evidence for a quilted bodyplan: Proceedings of the National Academy of Sciences of the United States of America, v. 102 p. 10227-10232, doi:10.1073/pnas.0502176102.

Xiao, S., Droser, M., Gehling, J.G., Hughes, I.V., Wan, B., Chen, Z., and Yuan, X., 2013, Affirming life aquatic for the Ediacara biota in China and Australia: Geology, v. 41, p. 1095-1098, doi:10.1130/G35364Y.1.

Xiao, S., Chen, Z., Zhou, C., and Yuan, X., 2019, Surfing in and on microbial mats: Oxygen-related behavior of a terminal Ediacaran bilaterian animal Geology, v. 47, p. 1054-1058, doi:10.1130/G46474.1.

Zhao, Z., Xing, Y., Ding, Q., Liu, G., Zhao, Y., Zhang, S., Meng, X., Yin, C., Ning, B., and Han, P., 1988, The Sinian System of Hubei: Wuhan, China University of Geosciences Press, 205 p. [in Chinese]

Zhou, C., and Xiao, S., 2007, Ediacaran $\delta^{13} \mathrm{C}$ chemostratigraphy of South China: Chemical Geology, v. 237, p. 89-108, doi:10.1016/j.chemgeo.2006. 06.021 .

Zhu, M., Gehling, J.G., Xiao, S., Zhao, Y., and Droser, M.L., 2008, Eightarmed Ediacara fossil preserved in contrasting taphonomic windows from China and Australia: Geology, v. 36, p. 867-870, doi:10.1130/G25203A.1.

Accepted: 5 June 2020 